\title{
Chemical characterization of fine particulate matter in Changzhou, China, and source apportionment with offline aerosol mass spectrometry
}

\author{
Zhaolian Ye ${ }^{1,2}$, Jiashu Liu ${ }^{1}$, Aijun Gu${ }^{1}$, Feifei Feng ${ }^{1}$, Yuhai Liu ${ }^{1}$, Chenglu Bi ${ }^{1}$, Jianzhong $\mathrm{Xu}^{3}$, Ling $\mathrm{Li}^{2}$, Hui Chen ${ }^{2}$, \\ Yanfang Chen ${ }^{2}$, Liang Dai ${ }^{2}$, Quanfa Zhou ${ }^{1}$, and Xinlei Ge ${ }^{2}$ \\ ${ }^{1}$ College of Chemistry and Environmental Engineering, Jiangsu University of Technology, Changzhou 213001, China \\ ${ }^{2}$ Jiangsu Key Laboratory of Atmospheric Environment Monitoring and Pollution Control, \\ Collaborative Innovation Center of Atmospheric Environment and Equipment Technology, School of Environmental Sciences \\ and Engineering, Nanjing University of Information Science and Technology, Nanjing 210044, China \\ ${ }^{3}$ State Key Laboratory of Cryospheric Sciences, Northwest Institute of Eco-Environment and Resources, \\ Chinese Academy of Sciences, Lanzhou 730000, China
}

Correspondence to: Xinlei Ge (caxinra@163.com)

Received: 4 October 2016 - Discussion started: 3 November 2016

Revised: 23 January 2017 - Accepted: 2 February 2017 - Published: 20 February 2017

\begin{abstract}
Knowledge of aerosol chemistry in densely populated regions is critical for effective reduction of air pollution, while such studies have not been conducted in Changzhou, an important manufacturing base and populated city in the Yangtze River Delta (YRD), China. This work, for the first time, performed a thorough chemical characterization on the fine particulate matter $\left(\mathrm{PM}_{2.5}\right)$ samples, collected during July 2015 to April 2016 across four seasons in this city. A suite of analytical techniques was employed to measure the organic carbon (OC), elemental carbon (EC), watersoluble organic carbon (WSOC), water-soluble inorganic ions (WSIIs), trace elements, and polycyclic aromatic hydrocarbons (PAHs) in $\mathrm{PM}_{2.5}$; in particular, an Aerodyne soot particle aerosol mass spectrometer (SP-AMS) was deployed to probe the chemical properties of water-soluble organic aerosol (WSOA). The average $\mathrm{PM}_{2.5}$ concentration was found to be $108.3 \mu \mathrm{g} \mathrm{m}^{-3}$, and all identified species were able to reconstruct $\sim 80 \%$ of the $\mathrm{PM}_{2.5}$ mass. The WSIIs occupied about half of the $\mathrm{PM}_{2.5}$ mass $(\sim 52.1 \%)$, with $\mathrm{SO}_{4}^{2-}, \mathrm{NO}_{3}^{-}$, and $\mathrm{NH}_{4}^{+}$as the major ions. On average, nitrate concentrations dominated over sulfate (mass ratio of 1.21), indicating that traffic emissions were more important than stationary sources. OC and EC correlated well with each other and the highest $\mathrm{OC} / \mathrm{EC}$ ratio (5.16) occurred in winter, suggesting complex OC sources likely in-
\end{abstract}

cluding both secondary and primary ones. Concentrations of eight trace elements ( $\mathrm{Mn}, \mathrm{Zn}, \mathrm{Al}, \mathrm{B}, \mathrm{Cr}, \mathrm{Cu}, \mathrm{Fe}, \mathrm{Pb}$ ) can contribute up to $\sim 5.0 \%$ of $\mathrm{PM}_{2.5}$ during winter. $\mathrm{PAH}$ concentrations were also high in winter $\left(140.25 \mathrm{ng} \mathrm{m}^{-3}\right)$, which were predominated by median/high molecular weight PAHs with five and six rings. The organic matter including both watersoluble and water-insoluble species occupied $\sim 21.5 \%$ of the $\mathrm{PM}_{2.5}$ mass. SP-AMS determined that the WSOA had average atomic oxygen-to-carbon $(\mathrm{O} / \mathrm{C})$, hydrogen-to-carbon $(\mathrm{H} / \mathrm{C})$, nitrogen-to-carbon $(\mathrm{N} / \mathrm{C})$, and organic matter-toorganic carbon $(\mathrm{OM} / \mathrm{OC})$ ratios of $0.54,1.69,0.11$, and 1.99 , respectively. Source apportionment of WSOA further identified two secondary OA (SOA) factors (a less oxidized and a more oxidized oxygenated OA) and two primary OA (POA) factors (a nitrogen-enriched hydrocarbon-like traffic $\mathrm{OA}$ and a local primary OA likely including species from cooking, coal combustion, etc.). On average, the POA contribution outweighed SOA ( $55 \%$ vs. $45 \%$ ), indicating the important role of local anthropogenic emissions in the aerosol pollution in Changzhou. Our measurement also shows the abundance of organic nitrogen species in WSOA, and the source analyses suggest these species are likely associated with traffic emissions, which warrants more investigations on PM samples from other locations. 


\section{Introduction}

Aerosol particles are ubiquitous in the atmosphere and play important roles in air quality, global climate, the biogeochemical cycle, human health, etc. (e.g., Heal et al., 2012; Cao et al., 2012; Hu et al., 2015). Aerosol pollution can also influence remote territories via long-range transport. Therefore, atmospheric aerosol has received extensive attention from the government, the public, and academia (e.g., Zhang et al., 2007a; Jimenez et al., 2009). In particular, much attention has focused on fine particles $\left(\mathrm{PM}_{2.5}\right.$, aerodynamic diameters less than $2.5 \mu \mathrm{m}$ ), as they can go deeper into the respiratory system, causing more severe health problems than coarse particles (Anderson et al., 2012). However, the concentrations, sources, chemical compositions, and formation mechanisms of $\mathrm{PM}_{2.5}$ are complicated and can vary greatly with meteorological conditions, seasons, regional/local topography, etc. $\mathrm{PM}_{2.5}$ can contain a variety of species, i.e., organic carbon (OC), elemental carbon (EC), trace elements, inorganic salts, and various organic species such as polycyclic aromatic hydrocarbons (PAHs) (e.g., Wang et al., 2015). In China, haze pollution has occurred frequently in recent years, and a large number of studies regarding the chemical characterization of fine particles were carried out in many locations (G. Wang et al., 2006), such as Shanghai (e.g., G. Wang et al., 2016; Zhao et al., 2015), Beijing (e.g., Sun et al., 2014, 2016; Hu et al., 2016), Nanjing (e.g., Zhang et al., 2016; Ding et al., 2013), Lanzhou (e.g., Fan et al., 2014; Xu et al., 2014), Wuhan (e.g., Huang et al., 2016), and other remote sites (Xu et al., 2015).

The Yangtze River Delta (YRD) region, located in eastern China, is experiencing severe atmospheric pollution along with the rapid economic development. Some studies carried out in the YRD investigated different characteristics of the fine aerosols, including the mass loading, composition, hygroscopicity (e.g., Ye et al., 2011; Ge et al., 2015), size distribution, seasonal variation, source, formation pathway, and their impacts on visibility and climate (e.g., Wang et al., 2012). However, these studies were mostly limited to Nanjing (e.g., Hu et al., 2012; Y. Wang et al., 2016) and Shanghai (e.g., Fu et al., 2012; Qiao et al., 2015; Wang et al., 2012). Changzhou, situated in the western YRD region, between Shanghai and Nanjing, is also a major city and an important manufacturing base due to its geographical advantage. The city has an area of about $4374 \mathrm{~km}^{2}$ with a population of 4.45 million. Due to elevated emissions of various pollutants, the number of hazy days increased over the past few years in Changzhou as well. To the best of our knowledge, no work has been published specifically on chemical characteristics and source apportionment of fine particles in Changzhou. Thus, it is scientifically and practically important to investigate the $\mathrm{PM}_{2.5}$ characteristics in order to provide efficient control strategies to reduce the PM pollution for Changzhou.

Among various $\mathrm{PM}_{2.5}$ constituents, organic aerosol (OA) is a vital component, accounting for a significant, even dom- inant, fraction of $\mathrm{PM}_{2.5}$ in ambient air (Zhang et al., 2007a). Thus, elucidation of its composition, properties, and sources is essential. Correct apportionment of OA into different sources is a critical step towards enabling efficient air pollution control strategies. Recently, Aerodyne aerosol mass spectrometry (AMS) has been used extensively for quantitatively characterizing ambient $\mathrm{OA}$, and the wealth of mass spectral data allows a better source analysis of OA (Canagaratna et al., 2007). In particular, positive matrix factorization (PMF), as a standard multivariate factor analysis method, has been widely applied to AMS datasets to distinguish and quantify the OA sources (Zhang et al., 2011). Many previous studies (e.g., Ge et al., 2012a; Ng et al., 2011) have deployed the AMS for online field measurements since AMS can provide real-time information on mass concentrations and size distributions of aerosol particles with very fine time resolutions (several seconds to minutes). However, up to now, AMS has typically been used for online measurements, and only a few studies have made efforts to apply it to offline filter sample analyses and source apportionment (Ge et al., 2014; Daellenbach et al., 2016; Y. Sun et al., 2011; Bozzetti et al., 2017; Mihara and Mochida, 2011; Huang et al., 2014; Xu et al., 2015).

In this study, for the first time, we systematically investigated the chemical characteristics of ambient $\mathrm{PM}_{2.5}$ collected in Changzhou across a nearly 1-year period, providing an overview of the concentrations of $\mathrm{PM}_{2.5}$, water-soluble inorganic ions (WSIIs), trace elements, carbonaceous species, water-soluble organic carbon (WSOC), PAHs, and the relationships between these components. Seasonal variations of different $\mathrm{PM}_{2.5}$ components were also discussed. Furthermore, we employed an Aerodyne soot particle aerosol mass spectrometer (SP-AMS) (Onasch et al., 2012; Lee et al., 2015; J. Wang et al., 2016b) to investigate the properties and potential sources of OA on the basis of high-resolution mass spectra determined by the SP-AMS. Findings from this study also add knowledge to the framework of the Pan-Eurasian Experiment (PEEX) (Kulmala et al., 2015).

\section{Experiments}

\subsection{Sampling site and $\mathbf{P M}_{2.5}$ collection}

The sampling site was set on the rooftop of a nine-story building inside the campus of Jiangsu University of Technology in Changzhou $\left(31.7^{\circ} \mathrm{N}, 119.9^{\circ} \mathrm{E}\right)$, as shown in Fig. 1. This site is located in the southwestern part of Changzhou, surrounded by a residential area, approximately $0.5 \mathrm{~km}$ away from an urban street, Zhongwu Road, and has no direct influences from industrial emissions (14.7 km away from the closest industrial plant - Bao Steel). Meteorological parameters including temperature, relative humidity $(\mathrm{RH})$, wind speed (WS), wind direction (WD), and concentrations of gas-phase species such as $\mathrm{SO}_{2}$ and $\mathrm{NO}_{2}$ are recorded by the air quality 


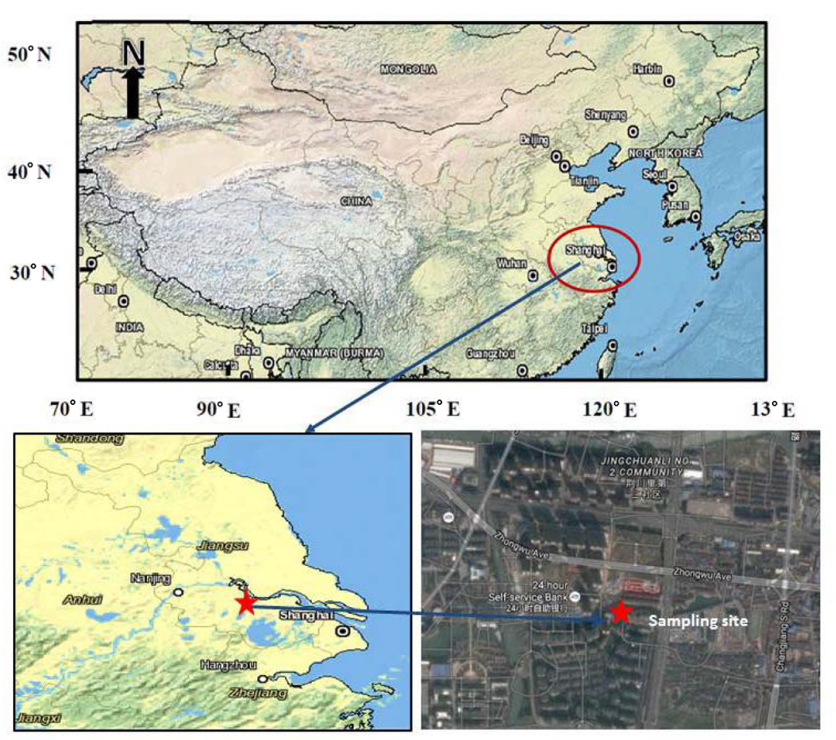

Figure 1. Schematic map of the sampling site and its surroundings.

monitoring station inside the campus, which is about $500 \mathrm{~m}$ away from the site. The average meteorological parameters of four seasons are shown in Table 1. The wind rose plots of different seasons are shown in Fig. S1 in the Supplement. The wind speed was generally low in Changzhou (on average, $1.1,1.6,0.9$, and $0.9 \mathrm{~m} \mathrm{~s}^{-1}$ in spring, summer, fall, and winter, respectively).

$\mathrm{PM}_{2.5}$ were collected onto $90 \mathrm{~mm}$ quartz fiber filters (Whatman, QM-A) using a medium volume sampler (TH$150 \mathrm{C}$, Wuhan Tianhong Ltd., China) with a flow rate of $100 \mathrm{~L} \mathrm{~min}^{-1}$. The filters, wrapped in aluminum foil, were prebaked at $450{ }^{\circ} \mathrm{C}$ for $4 \mathrm{~h}$ prior to sampling. The sampler began to collect particles at 09:00 and stopped at 05:00 of the following day, ensuring a duration time for each sample of $20 \mathrm{~h}$. A total of $69 \mathrm{PM}_{2.5}$ samples were collected: 20 July-19 August 2015 (summer, 11 samples), 18 September-25 October 2015 (fall, 23 samples), 7 December 2015-15 January 2016 (winter, 24 samples), and 1 March-12 April 2016 (spring, 11 samples).

Before and after sampling, the filters were conditioned under constant temperature $\left(22 \pm 1^{\circ} \mathrm{C}\right)$ and relative humidity $(45 \pm 5 \%)$ for $48 \mathrm{~h}$ and weighted by a microbalance (precision of $0.01 \mathrm{mg}$ ). The filters were then wrapped and sealed in aluminum foil envelopes separately, and stored in a freezer at $-20^{\circ} \mathrm{C}$ until analysis. Note that filter-based measurements are inevitably subjected to various sampling artifacts, including evaporation of semi-volatile species and absorption of gases. Nitrate in the form of ammonium nitrate may have some evaporation loss as it is sensitive to temperature variations during sampling, and absorption of gases may influence the quantification of particle-bound polycyclic aromatic hydrocarbons (PAHs).
Table 1. Average meteorological parameters during four seasons.

\begin{tabular}{|c|c|c|c|c|}
\hline Parameters & Spring & Summer & Fall & Winter \\
\hline RH $(\%)$ & $57.3 \pm 11.4$ & $61.1 \pm 11.8$ & $65.5 \pm 10.9$ & $62.3 \pm 10.6$ \\
\hline$T\left({ }^{\circ} \mathrm{C}\right)$ & $13.1 \pm 4.0$ & $32.1 \pm 4.3$ & $21.6 \pm 2.3$ & $5.6 \pm 1.8$ \\
\hline WS $\left(\mathrm{m} \mathrm{s}^{-1}\right)$ & $1.1 \pm 0.4$ & $1.6 \pm 0.6$ & $0.9 \pm 0.4$ & $0.9 \pm 0.3$ \\
\hline $\mathrm{WD}^{*}$ & SE & E, W, SE & $E$ & $\mathrm{~W}, \mathrm{NW}, \mathrm{SE}$ \\
\hline
\end{tabular}

\subsection{Chemical analysis}

\subsubsection{IC analysis}

One-quarter of a filter was put into a glass tube and $25 \mathrm{~mL}$ deionized water $\left(18.2 \mathrm{M} \Omega \mathrm{cm}^{-1}\right)$ was then added. After $45 \mathrm{~min}$ ultrasonic extraction, the solution was filtrated through an acetate-cellulose filter with $0.45 \mu \mathrm{m}$ pore size. Concentrations of the WSIIs in the aqueous extract, including five anions $\left(\mathrm{F}^{-}, \mathrm{Cl}^{-}, \mathrm{NO}_{2}^{-}, \mathrm{NO}_{3}^{-}, \mathrm{SO}_{4}^{2-}\right)$ and five cations $\left(\mathrm{Na}^{+}, \mathrm{NH}_{4}^{+}, \mathrm{K}^{+}, \mathrm{Mg}^{2+}, \mathrm{Ca}^{2+}\right)$, were then measured by the ion chromatograph (IC, Dionex ICS-600 for anions and ICS1500 for cations). The method detection limits (MDLs) were determined to be $18.0,7.3,5.2,6.3,11.0,18.7,3.3,4.6,2.6$, and $11.5 \mu \mathrm{g} \mathrm{L}^{-1}$ for $\mathrm{F}^{-}, \mathrm{Cl}^{-}, \mathrm{NO}_{2}^{-}, \mathrm{NO}_{3}^{-}, \mathrm{SO}_{4}^{2-}, \mathrm{Na}^{+}, \mathrm{NH}_{4}^{+}$, $\mathrm{K}^{+}, \mathrm{Mg}^{2+}$, and $\mathrm{Ca}^{2+}$, respectively, and all measured concentrations were above the MDLs. Note that the filter blanks were treated in the same way, and all data for the samples reported here were blank corrected; other analyses in the following sections were also blank corrected unless specified. The concentrations of all measured species in the $\mathrm{PM}_{2.5}$ sample were also converted to $\mu \mathrm{g} \mathrm{m}^{-3}$ based on the measured concentrations and the air volume pulled through the filter. The uncertainty of the IC measurements, calculated as 3 times the standard deviation of replicate measurements of blank filters, is shown in Table 2.

\subsubsection{ICP-OES analysis}

Another quarter of a filter was cut and placed in a Teflon vessel, digested with a $10 \mathrm{~mL}$ mixture of $\mathrm{HNO}_{3}-\mathrm{HCl}(1: 1$, $v: v$ ) in a microwave system (XT-9900A, Shanghai Xintuo Co.) for $45 \mathrm{~min}$. After the digested solution cooled down to room temperature, it was filtered through a $0.45 \mu \mathrm{m}$ acetatecellulose filter. The filtrate was then diluted using deionized water to $50 \mathrm{~mL}$, and analyzed using Optima 8000 (Perkin Elmer, USA) inductively coupled plasma optical emission spectrometry (ICP-OES) to determine the concentrations of eight trace elements $(\mathrm{Mn}, \mathrm{Zn}, \mathrm{Al}, \mathrm{B}, \mathrm{Cr}, \mathrm{Cu}, \mathrm{Fe}, \mathrm{Pb})$. It is worth mentioning that we also tried to measure the concentrations of other trace elements such as $\mathrm{Ti}, \mathrm{Ni}$, and $\mathrm{Ba}$, but found that they were mostly below the detection limits, and thus were not included in this work. All samples were determined in triplicate, and a difference within $5 \%$ was considered acceptable. Measurement uncertainties for trace metals 
Table 2. Summary of aerosol species, analytical methods, measurement uncertainties, and the method detection limits (MDLs).

\begin{tabular}{llll}
\hline Species & Analytical methods & Uncertainties & MDLs \\
\hline Water-soluble ions & Ion chromatography & $3.5-7.0 \%$ & $3-20 \mu \mathrm{g} \mathrm{L}^{-1}$ \\
Trace elements & ICP-OES & $10.3-18.5 \%$ & - \\
OC, EC & Thermal-optical carbon analyzer & $<12 \%$ & $30-80 \mathrm{ng} \mathrm{m}^{-3}{\text { for OC and } 30 \mathrm{ng} \mathrm{m}^{-3}}$ \\
WSOC & TOC analyzer & $3.4-6.0 \%$ & for EC (Mirante et al., 2014) \\
PAH & GC-MS & $20 \%$ & $2-5 \mu \mathrm{g} \mathrm{L} \mathrm{L}^{-1}$ \\
OM / OC ratio & SP-AMS & $6 \%($ Aiken et al., 2008) & - \\
WSOA & SP-AMS, TOC & $6.9-8.5 \%$ & - \\
\hline
\end{tabular}

were in the range of $10.3-18.5 \%$, with an average of $16.3 \%$ (Table 2).

\subsubsection{OC / EC and WSOC analysis}

The analysis procedure of OC / EC was similar to a previous study (Zhao et al., 2015). Briefly, OC and EC were measured by the DRI model 2001 thermal/optical carbon analyzer (Atmoslytic Inc., Calabasas, CA) using a $0.526 \mathrm{~cm}^{2}$ filter punch for each sample, following the IMPROVE TOR protocol (Chow et al., 2004). The filter was measured stepwise at temperatures of $140^{\circ} \mathrm{C}\left(\mathrm{OC}_{1}\right), 280^{\circ} \mathrm{C}\left(\mathrm{OC}_{2}\right), 480^{\circ} \mathrm{C}\left(\mathrm{OC}_{3}\right)$, and $580^{\circ} \mathrm{C}\left(\mathrm{OC}_{4}\right)$ under a helium atmosphere, and $580^{\circ} \mathrm{C}\left(\mathrm{EC}_{1}\right)$, $740{ }^{\circ} \mathrm{C}\left(\mathrm{EC}_{2}\right)$, and $840^{\circ} \mathrm{C}\left(\mathrm{EC}_{3}\right)$ under a $2 \%$ oxygen $/ 98 \%$ helium atmosphere. $\mathrm{OC}$ is calculated as $\mathrm{OC}_{1}+\mathrm{OC}_{2}+\mathrm{OC}_{3}+$ $\mathrm{OC}_{4}+\mathrm{OP}$ and $\mathrm{EC}$ as $\mathrm{EC}_{1}+\mathrm{EC}_{2}+\mathrm{EC}_{3}-\mathrm{OP}$, where OP is the optical pyrolyzed OC. The detection limit of OC was estimated to be $30-80 \mathrm{ng} \mathrm{m}^{-3}$ and EC was $\sim 30 \mathrm{ng} \mathrm{m}^{-3}$ based on a previous study (Mirante et al., 2014).

The WSOC concentrations were determined by a TOC analyzer (TOC-L, Shimazu, Japan) using a thermos-catalytic oxidation approach. Instrument details and the procedure of the WSOC analysis can be found in our previous work (Ge et al., 2014). The MDL was 5.0 $\mathrm{g} \mathrm{L}^{-1}$ and measurement uncertainties ranged from 3.4 to $6.0 \%$.

\subsubsection{GC-MS analysis for particulate PAHs}

Due to the limitation of samples, we only analyzed PAHs for spring and winter samples. The analysis was conducted following the standard procedure, similar to the work of Szabó et al. (2015). One-quarter of a filter was treated by Soxhelt extraction for $18 \mathrm{~h}$ using a $250 \mathrm{~mL}$ mixture of $n$ hexane/ethylether $(5: 1, v / v)$. To determine the recovery rates, $100 \mathrm{ng}$ of deuterated surrogate standard solution containing naphthalene- $d_{8}$ and perylene- $d_{12}$ (o2si, USA) was added to the sample prior to extraction, and the average recovery rates of $d_{8}$ and $d_{12}$ were over $90 \%$. The extracts were then concentrated to about $2 \mathrm{~mL}$ by a rotary evaporator, purified in a chromatography column (filled with $3 \mathrm{~cm}$ deactivated $\mathrm{Al}_{2} \mathrm{O}_{3}, 10 \mathrm{~g}$ silica gel, and $2 \mathrm{~cm}$ deactivated $\mathrm{Na}_{2} \mathrm{SO}_{4}$ ). The column was first eluted with $25 \mathrm{~mL} n$-hexane and the eluate was discarded; then elution was carried out using $30 \mathrm{~mL}$ dichloromethane $/ n$-hexane $(1: 1, v: v)$. Samples containing PAHs were again concentrated to about $2 \mathrm{~mL}$ by the rotary evaporation. Finally they were condensed to exactly $1 \mathrm{~mL}$ under a gentle $\mathrm{N}_{2}$ steam in a $60{ }^{\circ} \mathrm{C}$ water bath. The extracts are transferred into ampoule bottles and stored in a refrigerator until analysis.

The PAH compounds in the final extracts were analyzed with a gas chromatography mass spectrometer (GC-MS) (Agilent 7890-7000B, USA), using a DB-5ms capillary column $(30 \mathrm{~m} \times 0.25 \mathrm{~mm} \times 0.5 \mu \mathrm{m})$. The instrument conditions were set as follows: injector at $200^{\circ} \mathrm{C}$; ion source at $230^{\circ} \mathrm{C}$; the column was programmed at $40^{\circ} \mathrm{C}$ for $2 \mathrm{~min}$, then increased to $100^{\circ} \mathrm{C}$ at a rate of $10^{\circ} \mathrm{C} \mathrm{min}^{-1}$, held for $1 \mathrm{~min}$, then increased to $250^{\circ} \mathrm{C}$ at $20^{\circ} \mathrm{C} \mathrm{min}^{-1}$, and finally held for $3 \mathrm{~min}$ at $250^{\circ} \mathrm{C}$. The mass selective detector was operated in the electron impact mode using $70 \mathrm{eV}$. Multi-reaction monitor modes were employed for the identification and quantification of PAHs.

Before sample analysis, calibration standards at a series of concentrations were prepared from an aromatic hydrocarbon standard (O2si, USA) containing $18 \mathrm{PAH}$ compounds $\left(1000 \mathrm{mg} \mathrm{L}^{-1}\right)$, which are naphthalene $(\mathrm{NaP})$ $\left(\mathrm{C}_{10} \mathrm{H}_{8}\right)$, acenaphthylene (Acy) $\left(\mathrm{C}_{12} \mathrm{H}_{8}\right)$, acenaphthene (Ace) $\left(\mathrm{C}_{12} \mathrm{H}_{10}\right)$, fluorene (Flu) $\left(\mathrm{C}_{13} \mathrm{H}_{10}\right)$, phenanthrene (Phe) $\left(\mathrm{C}_{14} \mathrm{H}_{10}\right)$, anthracene (Ant) $\left(\mathrm{C}_{14} \mathrm{H}_{10}\right)$, fluoranthene (Flua) $\left(\mathrm{C}_{16} \mathrm{H}_{10}\right)$, pyrene $(\mathrm{Pyr})\left(\mathrm{C}_{16} \mathrm{H}_{10}\right)$, benzo(a)anthracene $(\mathrm{BaA})$ $\left(\mathrm{C}_{18} \mathrm{H}_{12}\right)$, chrysene $(\mathrm{Chr})\left(\mathrm{C}_{18} \mathrm{H}_{12}\right)$, benzo(b)fluoranthene (BbF) $\left(\mathrm{C}_{20} \mathrm{H}_{12}\right)$, benzo(k)fluoranthene $(\mathrm{BkF})\left(\mathrm{C}_{20} \mathrm{H}_{12}\right)$, benzo(a)pyrene (BaP) $\left(\mathrm{C}_{20} \mathrm{H}_{12}\right)$, Benzo(e)pyrene (BeP) $\left(\mathrm{C}_{20} \mathrm{H}_{12}\right)$, benzo(j)fluoranthene $(\mathrm{BjF})\left(\mathrm{C}_{20} \mathrm{H}_{12}\right)$, benzoperylene (BghiP) $\left(\mathrm{C}_{22} \mathrm{H}_{12}\right)$ indeno(1,2,3-cd)pyrene (InP) $\left(\mathrm{C}_{22} \mathrm{H}_{12}\right)$, and $\operatorname{dibenz}(\mathrm{a}, \mathrm{h})$ anthracene (DBA) $\left(\mathrm{C}_{22} \mathrm{H}_{14}\right)$. These PAHs can be classified by the number of aromatic rings and molecular weights: low molecular weight (LMW) PAHs containing two and three rings (NaP, Acy, Ace, Flu, Phe, Ant), medium molecular weight (MMW) PAHs containing four rings (Flua, Pyr, BaA, Chr), and high molecular weight (HMW) PAHs containing five and six rings $(\mathrm{BbF}$, $\mathrm{BkF}, \mathrm{BjF}, \mathrm{BaP}, \mathrm{BeP}$, InP, DBA, BghiP) (Wang et al., 2015; Kong et al., 2015). The calibration was conducted twice prior 
to analysis. Identification and quantification of each PAH are based on its retention time and peak areas in the calibration curve and sample curve, and the total PAH concentration $(\Sigma \mathrm{PAH})$ was calculated as the sum of concentrations of all 18 individual PAHs. Figure S2 shows examples of the GC-MS spectra of a few of the $18 \mathrm{PAH}$ standards and two surrogate standards ( $d_{8}$ and $\left.d_{12}\right)$.

\subsubsection{Offline SP-AMS analysis}

The Aerodyne AMS is specially designed for online and realtime measurements of the submicron aerosol particles. The instrument has a very fine time resolution and thus is powerful in capturing the quick atmospheric processes that occurred in the real atmosphere, while in this study we used the SP-AMS for offline filter sample analyses. Compared with the online measurements, there are a few advantages: (1) it can greatly expand the application of the AMS because it is often unrealistic to deploy the AMS for very long periods, as it requires highly skilled personal to carefully maintain and operate the instrument; (2) for some sites, it is not accessible or not suitable for AMS deployment; (3) AMS analysis of organics can provide more details, for instance the elemental composition and oxidation states, and thus can offer useful insights into the origin of OA; (4) offline analysis may introduce artifacts compared with the online measurements, but on the other hand, it also expands the size range, as online measurements were often limited in the submicron meter range.

The SP-AMS analysis procedure for offline filters was similar to that of Xu et al. (2013). Briefly, for each sample, a $1 / 4$ filter was extracted in $25 \mathrm{~mL}$ deionized water. The liquid extracts were aerosolized using an atomizer (TSI, Model 3076) and the mist passed through a silica-gel diffusion dryer, leaving dry particles which were subsequently analyzed by the SP-AMS. Note that the SP-AMS was operated with the laser off, similarly to other AMS measurements; it measured non-refractory organic species that can vaporize fast at the oven temperature of $600^{\circ} \mathrm{C}$. The instrument employs the $70 \mathrm{eV}$ electron impact (EI) ion generation scheme; all vaporized species were broken into ion fragments with specific mass-to-charge $(\mathrm{m} / \mathrm{z})$ ratios, and the time-of-flight mass spectrometer outputs the mass spectrum that records the ions according to their signal intensities at different $m / z$ ratios. Ion fragments with $m / z$ up to 300 amu were analyzed in this study. The SP-AMS mass spectra can well represent the total OA constituents, and the bulk OA properties such as elemental ratios including oxygen-to-carbon $(\mathrm{O} / \mathrm{C})$, hydrogen-to-carbon $(\mathrm{H} / \mathrm{C})$, and nitrogen-to-carbon $(\mathrm{N} / \mathrm{C})$ ratios, and the organic mass-to-organic carbon (OM/OC) ratio can be obtained. Note that although the SP-AMS is limited in molecular-level speciation analysis (Drewnick, 2012), some compounds can be identified via recognition of their corresponding fingerprint ions, and particular sources can be separated and quantified via further factor analyses.

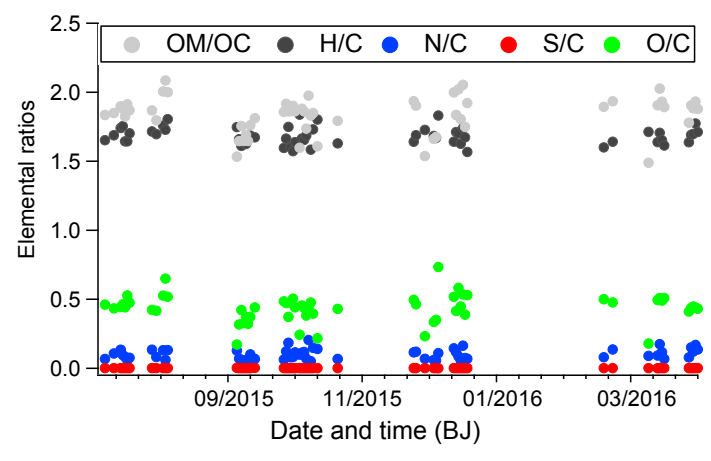

Figure 2. The atomic elemental ratios for the water-soluble organic aerosol (WSOA) determined by the SP-AMS.

The SP-AMS data were processed using Igorbased software toolkits SQUIRREL (version 1.56D) and PIKA (version 1.15D) (downloaded from http: //cires.colorado.edu/jimenez-group/ToFAMSResources/

ToFSoftware/index.html), and the analysis procedure was similar to our previous work (Ge et al., 2012b). We did some minor modifications on the fragment table. For example, we set the organic $\mathrm{CO}_{2}^{+}$signal equal to organic $\mathrm{CO}^{+}$, a factor the same as Aiken et al. (2008), as the $\mathrm{CO}_{2}^{+}$signal in $\mathrm{PM}_{2.5}$ may come from non-carbonate organics, and since we used Argon as a carrier gas so different from ambient measurements, the $\mathrm{CO}^{+}$signal can be well separated and quantified from $\mathrm{N}_{2}^{+}$at $m / z 28$ (example shown in Fig. S3). Note that the scatter plot of the original $\mathrm{CO}_{2}^{+}$vs. $\mathrm{CO}^{+}$ signals yielded a slope of 2.24. A recent AMS study using argon as a carrier gas on $\mathrm{PM}_{1}$ filter samples also showed a systematically higher $\mathrm{CO}_{2}^{+}$signal than $\mathrm{CO}^{+}$, but much less than the factor of 2.24, indicating that the $\mathrm{CO}_{2}^{+}$signal from the $\mathrm{PM}_{2.5}$ sample was influenced by $\mathrm{CO}_{2}^{+}$from carbonates. Accordingly, organic $\mathrm{H}_{2} \mathrm{O}^{+}, \mathrm{HO}^{+}$, and $\mathrm{O}^{+}$were scaled to $\mathrm{CO}_{2}^{+}$using the ratios proposed by Aiken et al. (2008), and the elemental compositions and $\mathrm{H} / \mathrm{C}, \mathrm{N} / \mathrm{C}, \mathrm{O} / \mathrm{C}$, and $\mathrm{OM} / \mathrm{OC}$ ratios of $\mathrm{OA}$ reported in this study were determined according to the method of Canagaratna et al. (2015).

\subsection{Determination of WSOA, WIOA}

Mass concentrations of WSOA were calculated by multiplying the WSOC concentrations determined from the TOC analyzer by the OM / OC ratios calculated from the SP-AMS mass spectra (Fig. 2) (Eq. 1). As shown in Fig. 2, most $\mathrm{OM} / \mathrm{OC}$ values were within the range of 1.5-2.3, consistent with the typical OM / OC ratios observed at other urban sites. However, the $\mathrm{O} / \mathrm{C}$ and $\mathrm{OM} / \mathrm{OC}$ ratios have no significant seasonal differences, indicating that the WSOA sources were likely similar.

The water-insoluble organic carbon (WIOC) mass was calculated as the difference between the OC determined by the 
OC / EC analyzer and the WSOC, and a factor of 1.3 suggested by Y. Sun et al. (2011) was used to convert the WIOC mass to the mass of water-insoluble organic aerosol (WIOA) (Eq. 2). The total organic aerosol (OA) was treated as the sum of WSOA and WIOA (Eq. 3).

$$
\begin{aligned}
& \mathrm{WSOA}=\mathrm{WSOC} \times \mathrm{OM} / \mathrm{OC}_{\mathrm{WSOA}} \\
& \mathrm{WIOA}=(\mathrm{OC}-\mathrm{WSOC}) \times 1.3 \\
& \mathrm{OA}=\mathrm{WSOA}+\mathrm{WIOA}
\end{aligned}
$$

The measurement uncertainty of WSOA was calculated as the sum of squares of uncertainties of $\mathrm{OM} / \mathrm{OC}$ ratios and WSOC, ranging from 6.9 to $8.5 \%$ (Table 2).

\subsection{Source apportionment of WSOA}

In this work, we used the PMF Evaluation Toolkit v 2.06 (Ulbrich et al., 2009) and followed the protocol described by Zhang et al. (2011) to conduct the PMF analyses. Typically, inclusion of more samples can provide better PMF results and more scientifically sound interpretation of the sources. But applications of the PMF model to a limited number of samples (much less than 100) were also reported previously (e.g., Huang et al., 2014; Y. Sun et al., 2011) and proven to be able to provide very valuable insights into the sources of OA.

Prior to PMF execution, the following steps were performed: data and error matrices for WSOA were first adjusted based on Eq. (1); ions with a low signal-to-noise ratio $(\mathrm{S} / \mathrm{N}<0.2)$ were removed, and ions with $\mathrm{S} / \mathrm{N}$ ratios between 0.2 and 2 were downweighted by a factor of 2 ; two runs with huge mass loading spikes were removed; all isotopic ions were removed since their signals are not measured directly but scaled to their parent ions. The PMF solutions were explored by varying the factors from 1 to 8 and the rotational forcing parameter $\left(f_{\text {peak }}\right)$ from -1 to 1 with an increment of 0.1 . The four-factor solution with $f_{\text {peak }}=0$ was chosen as the best solution. The mass spectra of three-factor and five-factor solutions were presented in Fig. S4. The threefactor solution does not resolve the oxygenated OA factors well, as many oxygenated ions were mixed with the primary OA factors. The five-factor solution splits a primary OA factor into two factors with very similar mass profiles. Also, by investigating the correlations of the factors with their corresponding tracer ions, and sulfate, nitrate, etc., of the three-, four-, and five-factor solutions, the four-factor solution was found to be the most reliable and representative solution.

\section{Results and discussion}

\subsection{Overview of $\mathbf{P M}_{2.5}$ concentrations and components}

The annual and seasonal average concentrations of $\mathrm{PM}_{2.5}$, OC, EC, OA, WSIIs, trace elements, and PAHs are summarized in Table 3. As shown in Table 3, the $\mathrm{PM}_{2.5}$ concentrations (in $\mu \mathrm{g} \mathrm{m}^{-3}$ ) were on average $( \pm 1 \sigma) 106.0( \pm 24.4), 80.9$ $( \pm 37.7), 103.3( \pm 28.2)$, and $126.9( \pm 50.4)$ in spring, summer, fall, and winter, respectively, with an annual average of $108.3( \pm 40.8)$, comparable to the $\mathrm{PM}_{2.5}$ concentrations in Nanjing (106 $\mathrm{\mu g} \mathrm{m}^{-3}$ in 2011) (Shen et al., 2014), Tian-

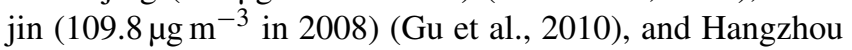
(108.2 $\mu \mathrm{g} \mathrm{m}^{-3}$ in 2004-2005) (Liu et al., 2015), but lower than that in Jinan (169 $\mathrm{g} \mathrm{m} \mathrm{m}^{-3}$ in 2010) (Gu et al., 2014). The $\mathrm{PM}_{2.5}$ concentrations were highest in winter and relatively low in summer, similar to those found in most cities, such as Tianjin (Gu et al., 2010) and Hangzhou (Liu et al., 2015). Previous studies showed that low concentrations occurring in summer were mainly due to the relatively high boundary layer height, low $\mathrm{RH}$, and high temperature (Cheng et al., 2015; Huang et al., 2010). The temperatures and RH values were on average $32.1^{\circ} \mathrm{C}$ and $61.1 \%$ in summer during the observation period (Table 1). Overall, the daily average concentration of $\mathrm{PM}_{2.5}$ during the sampling period exceeds $75 \mu \mathrm{g} \mathrm{m}^{-3}$ - the second-grade national ambient air quality standard (NAAQS) (GB3095-2012) - and on some heavily polluted days, the $\mathrm{PM}_{2.5}$ mass loadings can even exceed 3 times the NAAQS standard.

Overall, the reconstructed $\mathrm{PM}_{2.5}$ mass estimated by the sum of OA, EC, and WSIIs vs. gravimetrically determined $\mathrm{PM}_{2.5}$ mass was shown in Fig. 3a-d. The mass proportions of all measured components to the $\mathrm{PM}_{2.5}$ mass are illustrated by five inserted pie charts representing the four seasons and the whole year, respectively. On average, the quantified species can occupy $78.6 \%$ of the $\mathrm{PM}_{2.5}$ mass (note that trace elements and PAHs were not included as they were only determined for partial samples), and the mass closure appears to be better for spring and winter samples. Overall, our results are similar to some previous results, such as in Beijing (68\%) (Zhang et al., 2013). Details and characteristics of individual components are discussed in the following sections.

\subsection{Water-soluble inorganic ions}

The average concentrations $( \pm \sigma)$ of total WSIIs were $66.5( \pm 17.2), \quad 35.0( \pm 20.2), \quad 51.0 \quad( \pm 17.2), \quad$ and 66.8 $( \pm 23.6) \mu \mathrm{g} \mathrm{m}^{-3}$ in spring, summer, fall, and winter, respectively, with an annual average of $56.4( \pm 22.9) \mu \mathrm{g} \mathrm{m}^{-3}$. The level was lowest in summer, likely due to the conditions favorable for pollutant dispersion and the wet scavenging of these ions under summer monsoon circulation and precipitation. In total, all WSIIs can account for 62.7, 43.2, 49.3, and $52.6 \%$ of $\mathrm{PM}_{2.5}$ mass in spring, summer, fall, and winter, respectively, with the annual average WSIIs/ $\mathrm{PM}_{2.5}$ percentage 
Table 3. Summary of the mean concentrations (with 1 standard deviation) and mass fractions for $\mathrm{PM}_{2.5}$ and all quantified components in four seasons and the whole sampling period, respectively.

\begin{tabular}{|c|c|c|c|c|c|}
\hline Species $\left(\mu \mathrm{g} \mathrm{m}^{-3}\right)$ & Spring & Summer & Fall & Winter & Annual \\
\hline $\mathrm{PM}_{2.5}$ & $106.0 \pm 24.4$ & $80.9 \pm 37.7$ & $103.3 \pm 28.2$ & $126.9 \pm 50.4$ & $108.3 \pm 40.8$ \\
\hline WSIIs & $66.5 \pm 17.2$ & $35.0 \pm 20.2$ & $51.0 \pm 17.2$ & $66.8 \pm 23.6$ & $56.4 \pm 22.9$ \\
\hline Sulfate & $17.3 \pm 4.8$ & $15.8 \pm 9.8$ & $17.2 \pm 6.2$ & $18.7 \pm 7.6$ & $17.5 \pm 7.1$ \\
\hline Nitrate & $26.4 \pm 8.7$ & $6.8 \pm 6.2$ & $17.0 \pm 9.0$ & $24.1 \pm 11.8$ & $19.3 \pm 11.6$ \\
\hline Ammonium & $14.8 \pm 4.2$ & $8.2 \pm 4.3$ & $11.2 \pm 3.2$ & $13.1 \pm 3.7$ & $12.0 \pm 4.2$ \\
\hline Other ions & $8.0 \pm 2.3$ & $4.2 \pm 2.9$ & $5.6 \pm 1.5$ & $10.9 \pm 3.4$ & $7.6 \pm 3.7$ \\
\hline$\%$ of $\mathrm{PM}_{2.5}$ & $62.7 \pm 4.9$ & $43.2 \pm 7.4$ & $49.3 \pm 8.5$ & $52.6 \pm 7.3$ & $52.1 \pm 9.7$ \\
\hline $\mathrm{TC}$ & $16.0 \pm 3.3$ & $12.1 \pm 1.6$ & $21.0 \pm 11.8$ & $22.3 \pm 8.6$ & $19.2 \pm 9.3$ \\
\hline $\mathrm{OC}$ & $11.2 \pm 2.6$ & $7.9 \pm 0.8$ & $13.2 \pm 7.8$ & $18.3 \pm 8.1$ & $13.8 \pm 7.5$ \\
\hline $\mathrm{EC}$ & $4.8 \pm 0.9$ & $4.2 \pm 1.2$ & $7.7 \pm 4.5$ & $4.0 \pm 0.9$ & $5.4 \pm 3.2$ \\
\hline$\%$ of $\mathrm{PM}_{2.5}$ & $15.0 \pm 2.5$ & $15.0 \pm 6.5$ & $20.3 \pm 8.2$ & $17.6 \pm 3.3$ & $17.8 \pm 6.1$ \\
\hline $\mathrm{OA}$ & $18.9 \pm 4.1$ & $14.0 \pm 1.4$ & $21.6 \pm 11.9$ & $31.2 \pm 11.9$ & $23.3 \pm 9.0$ \\
\hline WSOA & $14.1 \pm 3.0$ & $12.1 \pm 2.4$ & $15.6 \pm 6.6$ & $25.1 \pm 8.6$ & $18.1 \pm 6.1$ \\
\hline WIOA & $4.8 \pm 2.6$ & $1.9 \pm 1.8$ & $5.9 \pm 7.2$ & $6.1 \pm 10.6$ & $5.2 \pm 7.6$ \\
\hline$\%$ of $\mathrm{PM}_{2.5}$ & $17.8 \pm 3.2$ & $18.2 \pm 8.4$ & $20.9 \pm 8.3$ & $24.6 \pm 6.3$ & $21.5 \pm 6.8$ \\
\hline PAHs (ng m ${ }^{-3}$ ) & $41.42 \pm 24.7$ & & & $140.25 \pm 60.2$ & \\
\hline Trace elements & & & $2.77 \pm 1.15$ & $6.38 \pm 3.14$ & \\
\hline $\mathrm{OA}+\mathrm{EC}+\mathrm{WSIIs}$ & $90.2 \pm 21.0$ & $53.2 \pm 21.6$ & $83.1 \pm 29.6^{*}$ & $108.4 \pm 36.3 *$ & $85.1 \pm 27.9$ \\
\hline$\%$ of $\mathrm{PM}_{2.5}$ & $85.1 \pm 5.6$ & $65.8 \pm 5.4$ & $80.4 \pm 15.0^{*}$ & $85.4 \pm 12.9 *$ & $78.6 \pm 11.6$ \\
\hline
\end{tabular}

* These values also include contributions from trace elements.
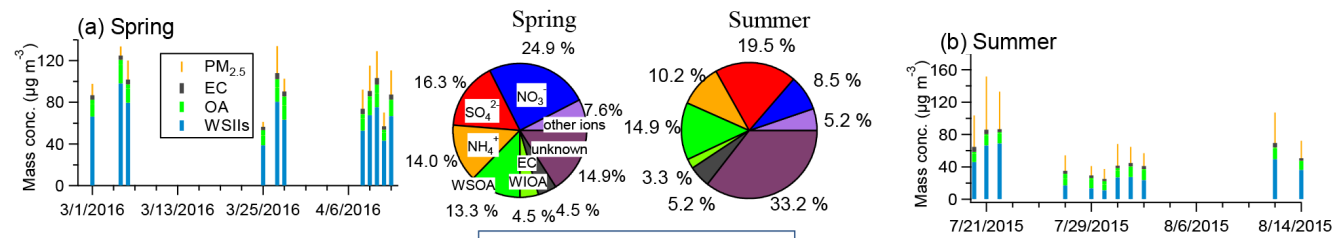

(trace metals and PAHs not included)
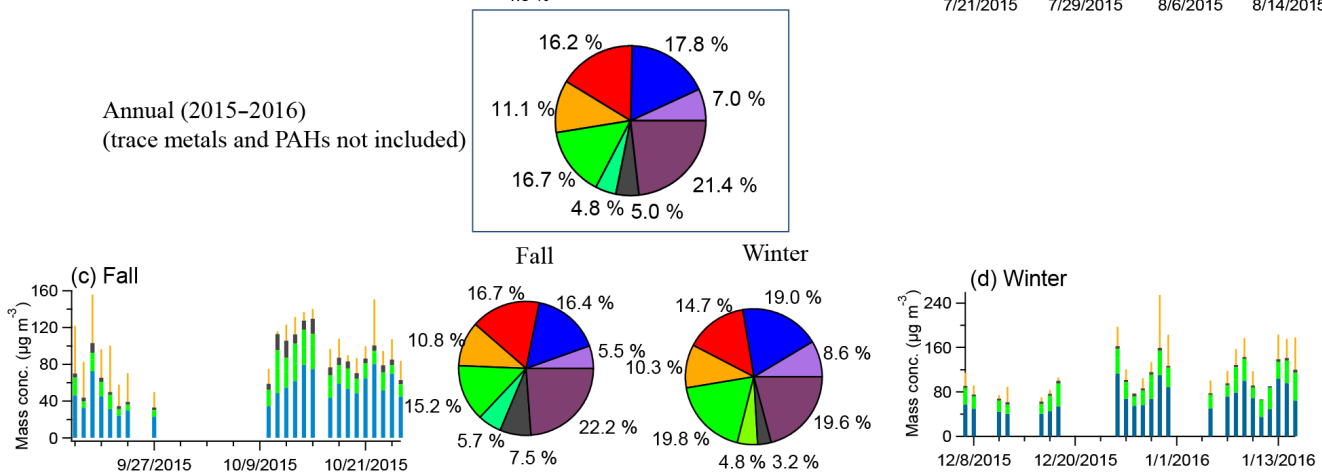

Figure 3. Reconstructed mass (= OA + EC + WSIIs) vs. $\mathrm{PM}_{2.5}$ mass from gravimetric measurement in (a) spring, (b) summer, (c) fall, (d) winter, and annual. Corresponding pie charts show the mass percentages of different species to the $\mathrm{PM}_{2.5}$ mass (trace elements and PAHs are not included due to sample limitations).

of $52.1 \%$, a little higher than the previously reported value of $45.3 \%$ in Handan in 2013 (Meng et al., 2016).

The mass fractions of individual ions to total WSIIs followed the order $\mathrm{NO}_{3}^{-}(34.2 \%)>\mathrm{SO}_{4}^{2-}(31.0 \%)>\mathrm{NH}_{4}^{+}$ $(21.2 \%)>\mathrm{Cl}^{-}(6.0 \%)>\mathrm{Na}^{+}(3.8 \%)>\mathrm{K}^{+}(1.8 \%)>\mathrm{Ca}^{2+}$ $(1.2 \%)>\mathrm{Mg}^{2+}(0.3 \%)>\mathrm{NO}_{2}^{-}$and $\mathrm{F}^{-}(0.2 \%)$ (Fig. $4 \mathrm{~b}$ ). Secondary inorganic ions, including $\mathrm{SO}_{4}^{2-}, \mathrm{NO}_{3}^{-}$, and $\mathrm{NH}_{4}^{+}$, constitute the majority of WSIIs $(86.4 \%)$ (Fig. 4b), with the highest one being $\mathrm{NO}_{3}^{-}$. Nitrate and ammonium concentrations displayed distinct seasonal variations - highest in spring $\left(\mathrm{NO}_{3}^{-}: 26.4 \mu \mathrm{g} \mathrm{m}^{-3} ; \mathrm{NH}_{4}^{+}: 14.8 \mu \mathrm{g} \mathrm{m}^{-3}\right)$, followed by winter $\left(24.1\right.$ and $\left.13.1 \mathrm{\mu g} \mathrm{m}^{-3}\right)$, and lowest in summer $\left(6.8\right.$ and $\left.8.2 \mu \mathrm{g} \mathrm{m}^{-3}\right)$. On the other hand, as a non-volatile 

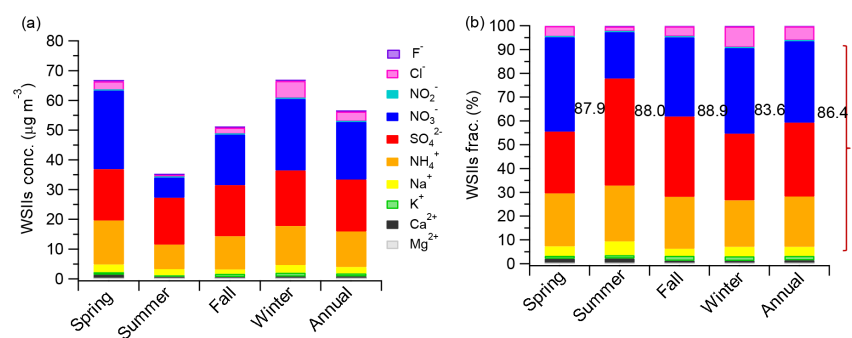

Figure 4. (a) Seasonal variations of average mass concentrations and (b) mass fractional contributions of WSIIs in $\mathrm{PM}_{2.5}$ in Changzhou during 2015-2016. The values marked in (b) are the fractions of the three most abundant ions $\left(\mathrm{NO}_{3}^{-}+\mathrm{SO}_{4}^{2-}+\mathrm{NH}_{4}^{+}\right)$in the total WSIIs.

species, sulfate concentrations showed no obvious seasonal differences.

The cross-correlation relationships between different ions can be used to infer their possible common sources. Figure 5 shows Pearson's correlation coefficients $(r)$ between ions for four seasons, respectively. As illustrated, $\mathrm{NH}_{4}^{+}$had good correlations with $\mathrm{SO}_{4}^{2-}$ and $\mathrm{NO}_{3}^{-}(r>0.70)$, and particularly high $r$ values were found in winter (with $\mathrm{SO}_{4}^{2-}$ : $r=0.90$; with $\mathrm{NO}_{3}^{-}: r=0.96$ ) and summer (with $\mathrm{SO}_{4}^{2-}$ : $r=0.98$; with $\mathrm{NO}_{3}^{-}: r=0.93$ ), indicating these three ions were mainly present in the form of ammonium nitrate and ammonium sulfate. Moreover, the correlations between $\mathrm{Na}^{+}$ and $\mathrm{Cl}^{-}$varied largely with the seasons, poor in summer $(r=$ $-0.19)$ and winter $(r=0.37)$, indicating different sources for them. For chloride, the annual average $\mathrm{Cl}^{-} / \mathrm{Na}^{+}$mass ratio was 1.58 , larger than the 1.17 in seawater (Zhang et al., 2013), indicating the important contributions of anthropogenic activities to chloride (such as coal combustion) in Changzhou, in particular in winter as the content of $\mathrm{Cl}^{-}$in winter was significantly elevated. By contrast, $\mathrm{K}^{+}$and $\mathrm{Cl}^{-}$ had good correlations ( $r$ of $0.86,0.76,0.80$, and 0.62 in spring, summer, fall, and winter), suggesting that $\mathrm{K}^{+}$may co-emit with chloride. According to the correlation analysis in Fig. 5, $\mathrm{Mg}^{2+}$ and $\mathrm{Ca}^{2+}$ had good relations, with $r$ of 0.58 , $0.80,0.81$, and 0.78 in spring, summer, fall, and winter, respectively, indicating a similar source, likely crustal material, of these two ions.

Acidity of $\mathrm{PM}_{2.5}$ can be evaluated by $\mathrm{AE}$ (anion equivalence) vs. CE (cation equivalence), which is calculated by converting the concentrations of anions and cations $\left(\mu \mathrm{g} \mathrm{m}^{-3}\right)$ into molar concentrations $\left(\mu \mathrm{mol} \mathrm{m}{ }^{-3}\right)$ using the following equations.

$$
\begin{aligned}
& \mathrm{AE}=\frac{\mathrm{SO}_{4}^{2-}}{48}+\frac{\mathrm{NO}_{3}^{-}}{62}+\frac{\mathrm{NO}_{2}^{-}}{46}+\frac{\mathrm{Cl}^{-}}{35.5}+\frac{\mathrm{F}^{-}}{19} \\
& \mathrm{CE}=\frac{\mathrm{NH}_{4}^{+}}{18}+\frac{\mathrm{Mg}^{2+}}{12.2}+\frac{\mathrm{Ca}^{2+}}{20}+\frac{\mathrm{K}^{+}}{39}+\frac{\mathrm{Na}^{+}}{23}
\end{aligned}
$$

Figure $6 \mathrm{a}$ illustrates the scatter plots of CE vs. AE in four seasons. The slopes were $1.18,1.09,1.03$, and 0.93 in
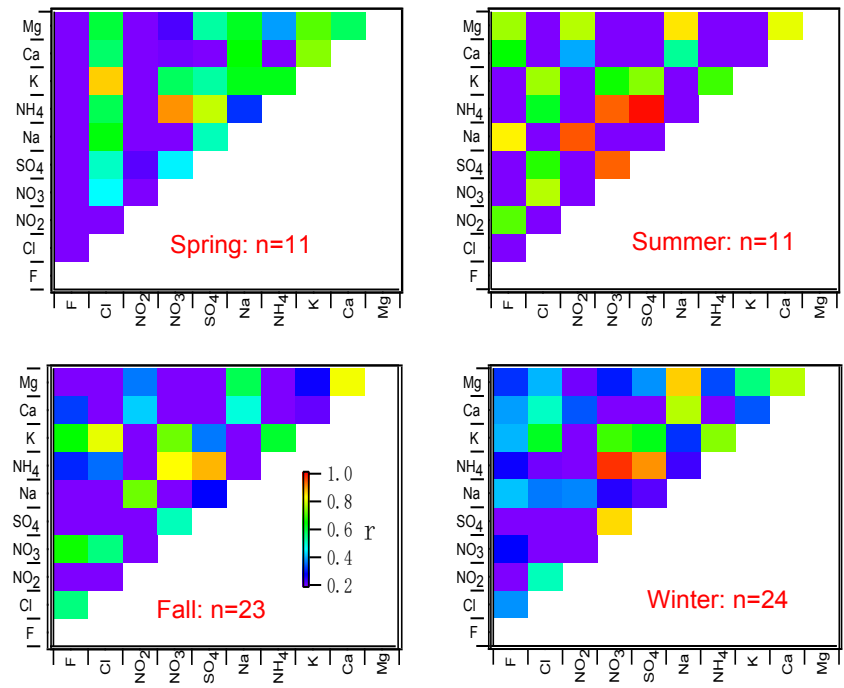

Figure 5. Image plots showing the cross-correlation coefficients $(r)$ between water-soluble ions in $\mathrm{PM}_{2.5}$ in four seasons (colored by $r$ ).

spring, summer, fall, and winter, respectively, indicating the particles are generally neutralized. Normally, the ratio of $\mathrm{NH}_{4}^{+}$meas $/ \mathrm{NH}_{4}^{+}$pred , proposed by Zhang et al. (2007b), can be used to evaluate the existing form of the $\mathrm{NH}_{4}^{+}$ion. The predicted $\mathrm{NH}_{4}^{+}\left(\mathrm{NH}_{4}^{+}\right.$pred $)$was calculated using Eq. (6).

$\mathrm{NH}_{4 \text { pred }}^{+}=18 \times\left(2 \times \frac{\mathrm{SO}_{4}^{2-}}{96}+\frac{\mathrm{NO}_{3}^{-}}{62}+\frac{\mathrm{Cl}^{-}}{35.5}\right)$

Figure S5 illustrated the ratio of $\mathrm{NH}_{4}^{+}$meas $/ \mathrm{NH}_{4}^{+}$pred in $\mathrm{PM}_{2.5}$ during four seasons. As presented, the ratios were $0.95,0.93,0.87$, and 0.75 in spring, summer, fall, and winter, respectively, again verifying that $\left(\mathrm{NH}_{4}\right)_{2} \mathrm{SO}_{4}, \mathrm{NH}_{4} \mathrm{NO}_{3}$, and $\mathrm{NH}_{4} \mathrm{Cl}$ were the dominant forms of these ionic species.

In addition, the mass ratio of $\mathrm{NO}_{3}^{-}$to $\mathrm{SO}_{4}^{2-}\left(\mathrm{NO}_{3}^{-} / \mathrm{SO}_{4}^{2-}\right)$ can be used to determine whether mobile sources (vehicles) or stationary sources (coal combustion) are dominant for these ions (Y. Wang et al., 2006; Arimoto et al., 1996). When the $\mathrm{NO}_{3}^{-} / \mathrm{SO}_{4}^{2-}$ mass ratio exceeds 1 , it means that particle sources at the observation site are likely dominated by mobile sources, while fixed sources play major roles when the ratio is below 1 . In this study, the mass ratios of $\mathrm{NO}_{3}^{-} / \mathrm{SO}_{4}^{2-}$ were $1.52,0.43,0.99$, and 1.29 in the spring, summer, fall, and winter, respectively, with an annual average ratio of 1.21 (Fig. 6b). The $\mathrm{NO}_{3}^{-} / \mathrm{SO}_{4}^{2-}$ ratio varied largely with seasons. Note that, in summer, a lower $\mathrm{NO}_{3}^{-} / \mathrm{SO}_{4}^{2-}$ ratio may be also ascribed to high temperature, which leads to the evaporation of $\mathrm{NH}_{4} \mathrm{NO}_{3}$, yet the high $\mathrm{NO}_{3}^{-} / \mathrm{SO}_{4}^{2-}$ in winter and spring is more likely relevant to traffic emissions from Zhongwu Road near the sampling site (Fig. 1).

Previous studies (Xu et al., 2014) have indicated that the nitrogen oxidation ratio $\left(\mathrm{NOR}=n \mathrm{NO}_{3}^{-} /\left(n \mathrm{NO}_{3}^{-}+n \mathrm{NO}_{2}\right)\right.$; $n$ refers to the molar concentration) and the sulfur oxidation 

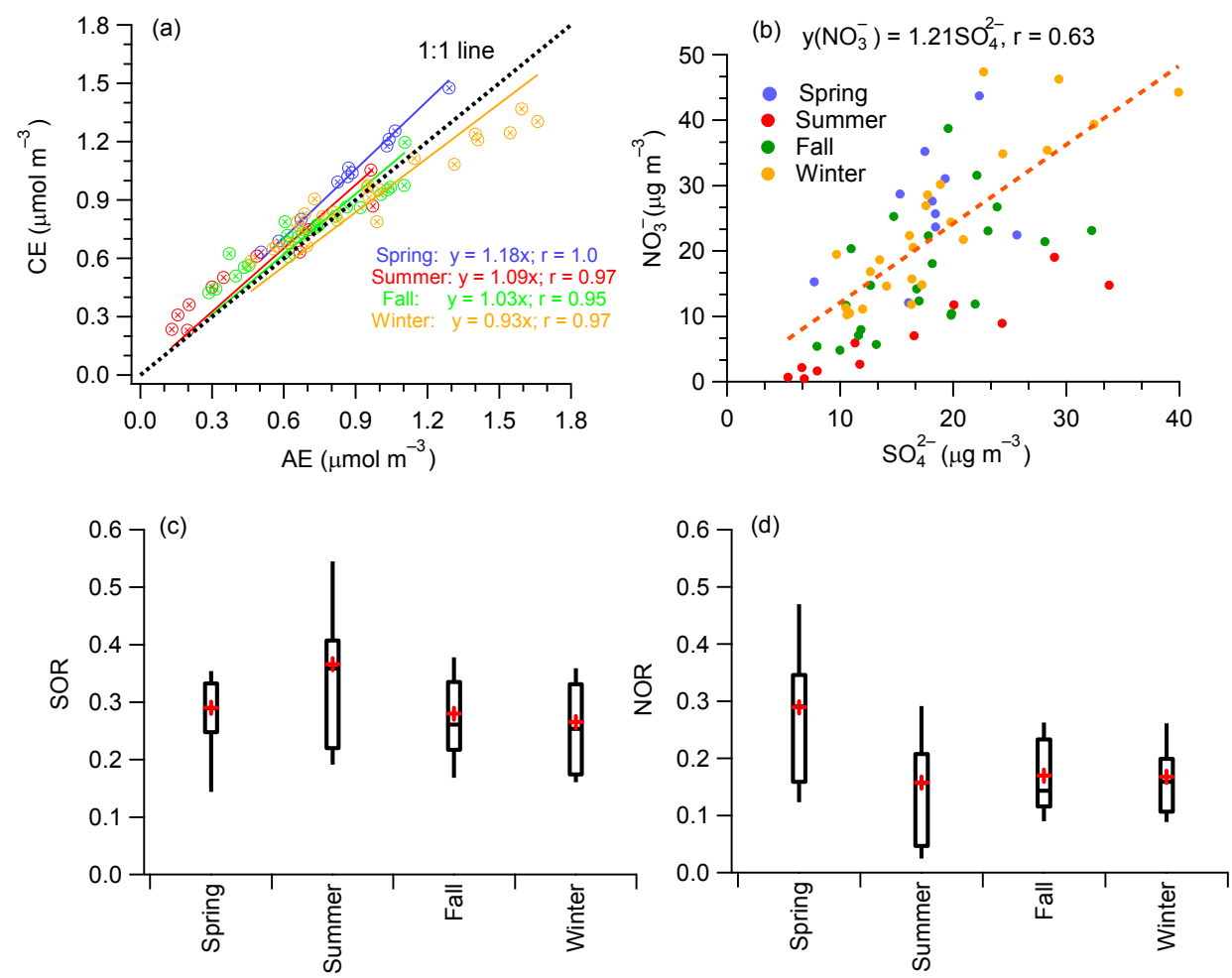

Figure 6. (a) Scatter plots of molar concentrations of cations vs. anions, (b) scatter plots of $\mathrm{NO}_{3}^{-}$vs. $\mathrm{SO}_{4}^{2-}$ concentrations, and (c-d) $\mathrm{SOR}$ and NOR values during the four seasons. In (a), the dashed line refers to the $1: 1$ line. In (b), the dashed line was the fitted line. Data in different seasons are shown by different colors for comparison. Linear regression equations were also presented. In (c-d), the crosses represent the mean, the middle bars represent the median, the top and bottom of the box represent the 75 th and 25 th percentiles, respectively, and the top and bottom whiskers represent the 90th and 10th percentiles, respectively.

ratio $\left(\mathrm{SOR}=n \mathrm{SO}_{4}^{2-} /\left(n \mathrm{SO}_{4}^{2-}+n \mathrm{SO}_{2}\right)\right)$ can be used to estimate the transformation of $\mathrm{NO}_{2}$ and $\mathrm{SO}_{2}$ to particle-phase $\mathrm{NO}_{3}^{-}$and $\mathrm{SO}_{4}^{2-}$. The larger SOR and NOR values mean more secondarily formed nitrate and sulfate. The seasonal values for SOR and NOR are plotted in Fig. 6c-d. On average, the SOR value appeared to be a bit higher in summer, indicating strong photochemical oxidation for sulfate formation, while NOR is relatively higher in spring, suggesting that conversion of $\mathrm{NO}_{x}$ into nitrate is more efficient in spring in Changzhou.

\subsection{Trace elements}

Eight trace elements ( $\mathrm{Mn}, \mathrm{Zn}, \mathrm{Al}, \mathrm{B}, \mathrm{Cr}, \mathrm{Cu}, \mathrm{Fe}, \mathrm{Pb})$ for samples collected during fall and winter were determined in this study. The average concentrations $\left(\mu \mathrm{g} \mathrm{m}^{-3}\right)$ are shown in Fig. 7a. The total concentrations were $6.38 \mu \mathrm{g} \mathrm{m}^{-3}$ and $2.77 \mu \mathrm{g} \mathrm{m}^{-3}$, accounting for 5.0 and $2.7 \%$ of the total $\mathrm{PM}_{2.5}$ mass during winter and fall, respectively. These values were relatively higher than those in other cities in China, such as $1.74-2.04 \%$ in Hangzhou (Liu et al., 2015). This probably can be explained by re-suspended dust from building construction around the site during the sampling period. In this study, the observed mean levels of trace elements in fall were in the order $\mathrm{Fe}>\mathrm{Zn}>\mathrm{B}>\mathrm{Al}>\mathrm{Cu}>\mathrm{Mn}>\mathrm{Pb}>\mathrm{Cr}$, and ranked $\mathrm{Zn}>\mathrm{Fe}>\mathrm{B}>\mathrm{Al}>\mathrm{Cu}>\mathrm{Mn}>\mathrm{Pb}>\mathrm{Cr}$ during winter (Fig. 7a). In fall, Fe accounted for $39.0 \%$ of the total trace metal mass, following by $\mathrm{Zn}(25.6 \%)$, B $(12.3 \%)$ and $\mathrm{Al}(9.2 \%)$, while in winter $\mathrm{Zn}$ contributed the most $(53.7 \%)$, following by $\mathrm{Fe}$ and B. Overall, $\mathrm{Fe}$ and $\mathrm{Zn}$ were the two most abundant trace elements in $\mathrm{PM}_{2.5}$, accounting for over half of the trace metal mass. Previous work also found that mass loading of $\mathrm{Zn}$ was higher than other elements, even higher than $\mathrm{Al}$ in Nanjing in 2013 (Qi et al., 2016b, a). Vehicle exhaust is likely one major contributor to the high concentration of $\mathrm{Zn}$.

In general, the correlations between various heavy metals are weak, as depicted in Fig. 7b-d, indicating the complex sources including both natural and anthropogenic sources for the trace metals observed here. For instance, $\mathrm{Cr}, \mathrm{Cu}, \mathrm{Pb}$, and $\mathrm{Zn}$ can be released from lubricating oils, tail pipe emissions, and brake and tire wear (Zhang et al., 2013); $\mathrm{Fe}$ and $\mathrm{Mg}$ are primarily crustal elements, while $\mathrm{Zn}$ and $\mathrm{Cu}$ are mainly from anthropogenic sources. Fe and $\mathrm{Al}$ were only moderately correlated (for example, in fall with $r=0.74$, Fig. 7b), showing that they are not from exactly the same sources. 
(a)

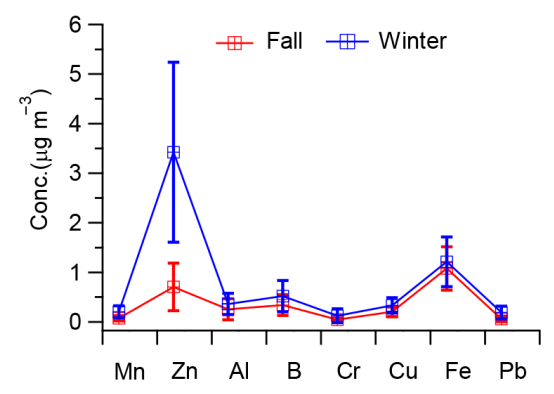

(c)

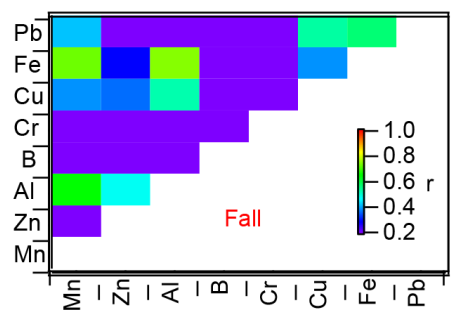

(b)

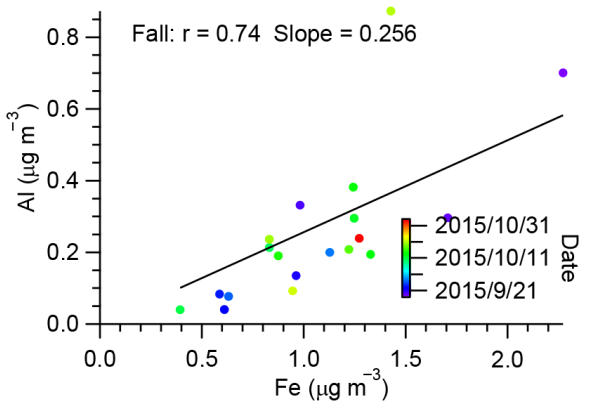

(d)

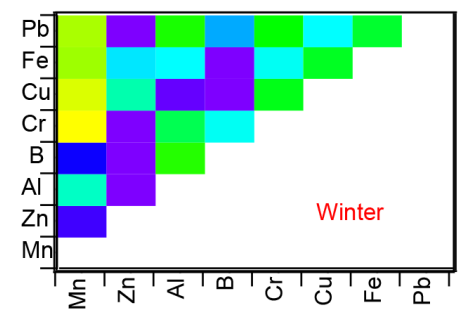

Figure 7. (a) Mean mass concentrations of trace elements determined for fall and winter (the error bar represents the measurement uncertainty), (b) scatter plots of $\mathrm{Al}$ vs. Fe in fall, and (c-d) cross-correlation coefficients $(r)$ among different trace elements in fall and winter, respectively (colored by $r$ ).

\subsection{OC and EC}

As presented in Table 3, the annual average EC concentration in Changzhou was $5.4 \mu \mathrm{g} \mathrm{m}^{-3}$, close to Nanjing $\left(5.3 \mu \mathrm{g} \mathrm{m}^{-3}\right)$ (Li et al., 2015) and Tianjin $\left(5.9 \mu \mathrm{g} \mathrm{m}^{-3}\right)$ (Gu et al., 2010), but lower than those in other cities, e.g., $22.3 \mu \mathrm{g} \mathrm{m}^{-3}$ in Beijing (Duan et al., 2012), and higher than that observed in Shanghai $\left(2.8 \mu \mathrm{g} \mathrm{m}^{-3}\right.$ ) (Feng et al., 2009). The seasonally averaged $\mathrm{OC}$ concentrations were highest in winter $\left(18.3 \mu \mathrm{g} \mathrm{m}^{-3}\right)$, followed by fall $\left(13.2 \mu \mathrm{g} \mathrm{m}^{-3}\right)$ and spring $\left(11.2 \mu \mathrm{g} \mathrm{m}^{-3}\right)$, and lowest in summer $\left(7.9 \mu \mathrm{g} \mathrm{m}^{-3}\right)$. The annual average OC concentration was $13.8 \mu \mathrm{g} \mathrm{m}^{-3}$, comparable to those measured in other cities, such as Shanghai $\left(14.7 \mu \mathrm{g} \mathrm{m}^{-3}\right.$ ) (Feng et al., 2009) and Tianjin $\left(16.9 \mu \mathrm{g} \mathrm{m}^{-3}\right)$ (Gu et al., 2010).

The mass concentrations of total carbon (TC, the sum of OC and EC) were 16.0, 12.1, 21.0, and $22.3 \mu \mathrm{g} \mathrm{m}^{-3}$ in spring, summer, fall, and winter, respectively (Table 3); the corresponding mass contributions to $\mathrm{PM}_{2.5}$ were 15.0, 15.0, 20.3 , and $17.6 \%$, with an annual mean of $17.8 \%$. This value was similar to those measured in other cities in China, such as Jinan (10-15\%) (Gu et al., 2014), Shanghai (15\%) (Zhao et al., 2015), and other cities (10-15\% in Tianjin, Haining, Zhongshan, and Deyang; Zhou et al., 2016). The OA concentrations exhibited similar seasonal variations to $\mathrm{PM}_{2.5}$, and ranked in the order winter $(31.2 \pm 11.9)>$ fall $(21.6 \pm 11.9)>$ spring $(18.9 \pm 4.1)>$ summer $(14.0 \pm 1.4)$. The average mass fraction of $\mathrm{OA}$ in $\mathrm{PM}_{2.5}$ was $21.5 \%$, and the WSOA contributed $77.7 \%$ of the total OA mass, similar

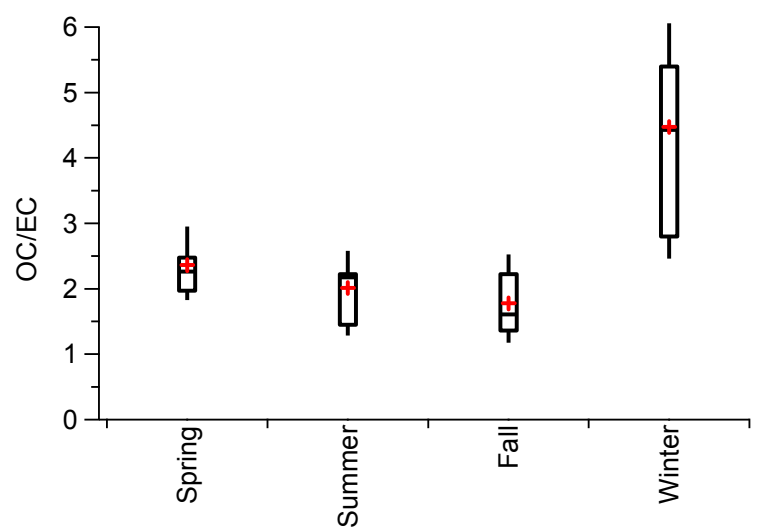

Figure 8. Average OC / EC ratios measured in four seasons (symbols of the box plots are the same as described in Fig. 6).

to the results in Atlanta (approximately $88 \%$ in rural Centreville and $77 \%$ in urban Atlanta) (Xu et al., 2017).

As illustrated in Fig. 8, the OC / EC ratios varied in different seasons and were largest in winter (5.16), followed by spring (2.38), summer (1.88), and fall (1.75). The largest $\mathrm{OC} / \mathrm{EC}$ ratio occurred in winter, indicating that secondary organic carbon (SOC) was likely a significant component of $\mathrm{PM}_{2.5}$ in winter (Chow et al., 2005); however, the high OC / EC ratio may be influenced by biomass burning and/or coal combustion emissions during wintertime too. A number of previous studies about the carbonaceous aerosols in the YRD region also showed that the highest OC / EC ra- 
tio occurred in winter, and the ratio was often larger than 2 , such as in Shanghai (6.35) (Zhao et al., 2015) and Nanjing (2.8) (Li et al., 2015), consistent with our current results in Changzhou.

\subsection{Particulate PAHs analysis with GC-MS and SP-AMS}

The average concentrations of the 18 individual PAH and total PAHs ( $\Sigma$ PAHs) in winter and spring are listed in Table 4. It can be seen that InP ( $\%$ of total PAH: 12.6-14.8\%), BghiP (10.8-12.3\%), and $\mathrm{Chr}(10.4-11.0 \%)$ were the three most abundant PAH species, followed by BbF (8.69-9.39\%), BaP (7.37-8.29\%), BeP (5.83-8.61\%), and BaA (4.53-8.27\%). The $\Sigma$ PAHs in $\mathrm{PM}_{2.5}$ were found in the range of 14.0$365.7 \mathrm{ng} \mathrm{m}^{-3}$ (mean: $140.25 \mathrm{ng} \mathrm{m}^{-3}$ ) and $8.9-91.3 \mathrm{ng} \mathrm{m}^{-3}$ (mean: $41.42 \mathrm{ng} \mathrm{m}^{-3}$ ) during winter and spring, respectively. The $\Sigma$ PAHs concentrations in this study are higher than those reported in Zhenzhou (39 and $111 \mathrm{ng} \mathrm{m}^{-3}$ in spring and winter) (Wang et al., 2014) and Shanghai (13.7 $\mathrm{ng} \mathrm{m}^{-3}$ in spring) (Wang et al., 2015), but lower than that reported in Liaoning Province (75-1900 $\mathrm{ng} \mathrm{m}^{-3}$ ) (Kong et al., 2010). PAHs with medium (four rings) and high molecular weights (five to six rings) (MMW and HMW) occupied the majority of the PAHs (88.9\% in winter and $79.4 \%$ in spring). It is well known that MMW and HMW PAHs are usually associated with coal combustion and vehicular emissions (Wang et al., 2015). A prior study in Nanjing (He et al., 2014) also showed the significant contribution of traffic exhaust to some PAHs, including BbF, Chr, Flu, InP, BeP, and BghiP, which in total accounted for more than $53 \%$ of the total PAHs.

The diagnostic ratios of selected PAHs, including BaP / BghiP, Flua / (Flua+Pyr), BaP / (BaP+Chr), and Phe / (Ant+Phe) can be used to further distinguish the emission sources of PAHs (Szabó et al., 2015). As suggested previously (Feng et al., 2015; Saldarriaga-Noreña et al., $2015)$, the traffic source was characterized by a ratio of $\mathrm{BaP} / \mathrm{BghiP}>0.6$, and ratios of Flua $/($ Flua + Pyr $)<0.4$, $0.4-0.5$, and $>0.5$ suggest sources of petrogenic, fossil fuel combustion, and coal/wood combustion, respectively. In this work, the Bap / BghiP ratios of 0.61 (winter) and 0.76 (spring) and the Flua / (Flua+Pyr) ratios of 0.47 (winter) and 0.50 (spring) all suggest that local vehicular/fossil fuel combustion emissions could be a prominent contributor to particulate PAHs, and the contribution from long-range transport was thus minor. Meanwhile, $\mathrm{BaP} /(\mathrm{BaP}+\mathrm{Chr})$ ratios of 0.40 (winter) and 0.44 (spring) also point to the source of gasoline emission (Khalili et al., 1995). However, the Phe / (Ant + Phe) ratios of 0.89 (winter) and 0.86 (spring) indicate that the coal combustion might also be an important source of PAHs.

On the other hand, by using the SP-AMS, we also identified a series of PAH ions, i.e., $\mathrm{C}_{16} \mathrm{H}_{10}^{+}(m / z 202), \mathrm{C}_{17} \mathrm{H}_{12}^{+}$ $(m / z 216), \mathrm{C}_{18} \mathrm{H}_{10}^{+}(m / z 226), \mathrm{C}_{18} \mathrm{H}_{12}^{+}(m / z 228), \mathrm{C}_{19} \mathrm{H}_{12}^{+}$ $(m / z 240), \mathrm{C}_{19} \mathrm{H}_{14}^{+}(m / z 242), \mathrm{C}_{20} \mathrm{H}_{10}^{+}(m / z 250), \mathrm{C}_{20} \mathrm{H}_{12}^{+}$ $(m / z 252), \mathrm{C}_{21} \mathrm{H}_{12}^{+}(m / z 264), \mathrm{C}_{21} \mathrm{H}_{14}^{+}(m / z 266), \mathrm{C}_{22} \mathrm{H}_{12}^{+}$ $(m / z 276), \mathrm{C}_{23} \mathrm{H}_{12}^{+}(m / z 288), \mathrm{C}_{23} \mathrm{H}_{14}^{+}(m / z 290), \mathrm{C}_{24} \mathrm{H}_{12}^{+}$ $(m / z 300), \mathrm{C}_{24} \mathrm{H}_{14}^{+}(m / z 302), \mathrm{C}_{25} \mathrm{H}_{16}^{+}(m / z 316), \mathrm{C}_{26} \mathrm{H}_{14}^{+}$ $(\mathrm{m} / \mathrm{z} 326)$, and $\mathrm{C}_{26} \mathrm{H}_{16}^{+}(\mathrm{m} / \mathrm{z}$ 328) (Dzepina et al., 2007). Note that many PAH ions identified by the SP-AMS were not measured by the GC-MS, and the PAH compound DBA which is determined by the GC-MS was not detected by the SP-AMS. This result reflects the different sensitivities and responses to the particle-bound PAHs of these two techniques. Table 5 shows the correlation $(r)$ coefficients of the concentrations of a few selected PAHs and the mass ratios of their concentrations measured by both the GC-MS and SP-AMS (results for the SP-AMS were based on measurements of all samples, while results for the GC-MS were for 23 samples in winter and spring). It can be seen that the concentrations of GC-MS-determined PAHs correlated very well with each other $(r>0.92)$, while the mass loadings determined by the SP-AMS correlated relatively weakly. Also, the mass ratios determined from these two instruments were different. The inconsistencies may be for the following reasons: (1) SPAMS broke the parent PAH molecules into fragments due to 70 ev EI; thus, the concentration of a specific PAH ion from the SP-AMS cannot represent its corresponding parent PAH compound, while the GC-MS determined the concentration of molecular PAH compound; (2) one PAH ion in the SPAMS high-resolution mass spectra (HRMS) may be a combination of a few PAH compounds with the same molecular weights; (3) sensitivities and responses to the different PAHs of the SP-AMS may be different, and thus may lead to uncertainties in the PAH quantification. Nevertheless, combining GC-MS and SP-AMS to improve the PAH measurements by the SP-AMS is valuable, and will be the subject of our future work.

\subsection{Source apportionment of WSOA}

\subsubsection{WSOA mass spectral profile}

To gain further insights into the particulate OA characteristics, we performed the SP-AMS analyses on the water extract of the $\mathrm{PM}_{2.5}$ samples, with a focus on OA. The averaged HRMS of WSOA classified by six ion categories and five elements are shown in Fig. 9, and the corresponding inset pie charts represent the mass percentages of the ion families and elements, respectively. As illustrated in Fig. 9a, the $\mathrm{C}_{x} \mathrm{H}_{y}^{+}$ion family accounts for $386.2 \%$ of the WSOA HRMS, followed by $\mathrm{C}_{x} \mathrm{H}_{y} \mathrm{O}^{+}(28.5 \%), \mathrm{C}_{x} \mathrm{H}_{y} \mathrm{~N}_{p}^{+}(17.7 \%)$, and $\mathrm{C}_{x} \mathrm{H}_{y} \mathrm{O}_{2}^{+}$ $(11.2 \%)$. It is worth mentioning that we found that the $\mathrm{C}_{x} \mathrm{H}_{y} \mathrm{~N}_{p}^{+}$ions contributed significantly, and the organic $\mathrm{N}$ (ON) could occupy $6.4 \%$ of the total WSOA mass (Fig. 9b). The average concentration of water-soluble organic nitrogen (WSON) over the sampling period was $1.16 \mu \mathrm{g} \mathrm{N} \mathrm{m}^{-3}$ $\left(83.0 \mathrm{nmol} \mathrm{N} \mathrm{m}^{-3}\right)$, which is in fact much lower than those measured in Beijing (226 nmol N m${ }^{-3}$ ) (Duan et al., 2009),

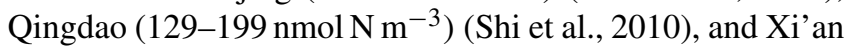


Table 4. Mean concentration $\left(\mathrm{ng} \mathrm{m}^{-3}\right)$ and mass fractions $(\%)$ of individual PAH to the total PAHs.

\begin{tabular}{|c|c|c|c|c|c|c|}
\hline \multirow[t]{2}{*}{ PAH compounds } & \multirow[t]{2}{*}{ Number of rings } & \multirow{2}{*}{$\begin{array}{l}\text { Molecular formula } \\
\text { and molecular weight } \\
\text { (MW) }\end{array}$} & \multicolumn{2}{|l|}{ Winter } & \multicolumn{2}{|l|}{ Spring } \\
\hline & & & $\begin{array}{l}\text { Conc. } \\
\left(\mathrm{ng} \mathrm{m}^{-3}\right)\end{array}$ & $\%$ of total & $\begin{array}{l}\text { Conc. } \\
\left(\mathrm{ng} \mathrm{m}^{-3}\right)\end{array}$ & $\%$ of total \\
\hline $\mathrm{NaP}$ & 2 rings & $\mathrm{C}_{10} \mathrm{H}_{8}, 128$ & 10.12 & 7.22 & 2.60 & 6.28 \\
\hline Acy & 3 rings & $\mathrm{C}_{12} \mathrm{H}_{8}, 152$ & 0.16 & 0.12 & 0.08 & 0.20 \\
\hline Ace & & $\mathrm{C}_{12} \mathrm{H}_{10}, 154$ & 0.15 & 0.11 & 0.34 & 0.83 \\
\hline Flu & & $\mathrm{C}_{13} \mathrm{H}_{10}, 166$ & 1.19 & 0.85 & 1.70 & 4.11 \\
\hline Phe & & $\mathrm{C}_{14} \mathrm{H}_{10}, 178$ & 3.54 & 2.52 & 3.24 & 7.83 \\
\hline Ant & & $\mathrm{C}_{14} \mathrm{H}_{10}, 178$ & 0.46 & 0.33 & 0.54 & 1.31 \\
\hline Flua & 4 rings & $\mathrm{C}_{16} \mathrm{H}_{10}, 202$ & 8.05 & 5.74 & 2.57 & 6.21 \\
\hline Pyr & & $\mathrm{C}_{16} \mathrm{H}_{10}, 202$ & 8.93 & 6.37 & 2.43 & 5.87 \\
\hline $\mathrm{BaA}$ & & $\mathrm{C}_{18} \mathrm{H}_{12}, 228$ & 11.6 & 8.27 & 1.88 & 4.53 \\
\hline $\mathrm{Chr}$ & & $\mathrm{C}_{18} \mathrm{H}_{12}, 228$ & 15.41 & 11.0 & 4.32 & 10.43 \\
\hline $\mathrm{BbF}+\mathrm{BjF}$ & 5 rings & $\mathrm{C}_{20} \mathrm{H}_{12}, 252$ & 12.19 & 8.69 & 3.89 & 9.39 \\
\hline $\mathrm{BkF}$ & & $\mathrm{C}_{20} \mathrm{H}_{12}, 252$ & 5.58 & 3.98 & 1.87 & 4.50 \\
\hline $\mathrm{BaP}$ & & $\mathrm{C}_{20} \mathrm{H}_{12}, 252$ & 10.33 & 7.37 & 3.43 & 8.29 \\
\hline $\mathrm{BeP}$ & & $\mathrm{C}_{20} \mathrm{H}_{12}, 252$ & 12.08 & 8.61 & 2.42 & 5.83 \\
\hline DBA & & $\mathrm{C}_{22} \mathrm{H}_{14}, 278$ & 2.53 & 1.8 & 0.42 & 1.02 \\
\hline $\mathrm{InP}$ & 6 rings & $\mathrm{C}_{22} \mathrm{H}_{12}, 276$ & 20.74 & 14.8 & 5.23 & 12.62 \\
\hline BghiP & & $\mathrm{C}_{22} \mathrm{H}_{12}, 276$ & 17.18 & 12.3 & 4.46 & 10.76 \\
\hline LMW-PAHs & $2-3$ rings & & 15.62 & 11.1 & 8.50 & 20.6 \\
\hline MMW-PAHs & 4 rings & & 43.99 & 31.4 & 11.20 & 27.0 \\
\hline HMW-PAHs & $5-6$ rings & & 80.63 & 57.5 & 21.72 & 52.4 \\
\hline$\Sigma$ PAHs & & & 140.25 & 100.0 & 41.42 & 100.0 \\
\hline
\end{tabular}

Table 5. Cross-correlation coefficients $(r)$ of the measured concentrations of the PAH species and ratios of the mean concentrations between these species from GC-MS (bold) and SP-AMS (italic).

\begin{tabular}{lrrrrrr}
\hline PAHs & $\mathrm{C}_{16} \mathrm{H}_{10}$ & $\mathrm{C}_{18} \mathrm{H}_{12}$ & $\mathrm{C}_{20} \mathrm{H}_{12}$ & $\mathrm{C}_{22} \mathrm{H}_{12}$ & Ratio (GC-MS) & Ratio (SP-AMS) \\
\hline $\mathrm{C}_{16} \mathrm{H}_{10}$ & 1 & -0.250 & -0.062 & -0.140 & $\mathbf{C}_{\mathbf{1 6}} \mathbf{H}_{\mathbf{1 0}} / \mathbf{C}_{\mathbf{1 6}} \mathbf{H}_{\mathbf{1 0}}=\mathbf{1}$ & $C_{16} H_{10}^{+} / C_{16} H_{10}^{+}=1$ \\
$\mathrm{C}_{18} \mathrm{H}_{12}$ & $\mathbf{0 . 9 5 2}$ & 1 & 0.572 & 0.528 & $\mathbf{C}_{\mathbf{1 6}} \mathbf{H}_{10} / \mathbf{C}_{\mathbf{1 8}} \mathbf{H}_{12}=\mathbf{0 . 8 4}$ & $C_{16} H_{10}^{+} / C_{18} H_{12}^{+}=0.43$ \\
$\mathrm{C}_{20} \mathrm{H}_{12}$ & $\mathbf{0 . 9 3 6}$ & $\mathbf{0 . 9 9 4}$ & 1 & 0.771 & $\mathbf{C}_{\mathbf{1 6}} \mathbf{H}_{10} / \mathbf{C}_{\mathbf{2 0}} \mathbf{H}_{12}=\mathbf{0 . 3 6}$ & $C_{16} H_{10}^{+} / C_{20} H_{12}^{+}=0.56$ \\
$\mathrm{C}_{22} \mathrm{H}_{12}$ & $\mathbf{0 . 9 2 5}$ & $\mathbf{0 . 9 8 6}$ & $\mathbf{0 . 9 9 3}$ & 1 & $\mathbf{C}_{\mathbf{1 6}} \mathbf{H}_{\mathbf{1 0}} / \mathbf{C}_{\mathbf{2 2}} \mathbf{H}_{\mathbf{1 2}}=\mathbf{0 . 3 5}$ & $C_{16} H_{10}^{+} / C_{22} H_{12}^{+}=1.17$ \\
\hline
\end{tabular}

$\mathrm{C}_{16} \mathrm{H}_{10}$ : Flua+Pyr; $\mathrm{C}_{18} \mathrm{H}_{10}: \mathrm{BaA}+\mathrm{Chr} ; \mathrm{C}_{20} \mathrm{H}_{12}: \mathrm{BbF}+\mathrm{BjF}+\mathrm{BkF}+\mathrm{BaP}+\mathrm{BeP}$;

$\mathrm{C}_{22} \mathrm{H}_{12}$ : BghiP+InP+DBA

$\left(300 \mathrm{nmol} \mathrm{N} \mathrm{m}^{-3}\right.$ ) (Ho et al., 2015). The concentration of water-soluble inorganic nitrogen (WSIN, $\mathrm{N}$ from ammonium, nitrate, and nitrite) was $14.0 \mu \mathrm{g} \mathrm{N} \mathrm{m}^{-3}$ based on Table 3, and thus the WSON content corresponds to $7.7 \%$ of water-soluble nitrogen $(\mathrm{WSN}=\mathrm{WSON}+\mathrm{WSIN})$. These values are also much lower than those in Beijing $(\sim 30 \%)$ (Duan et al., 2009), Qingdao (19-22.6\%), and Xi' an (22$68 \%$ ) (Ho et al., 2015).

Nevertheless, the levels of ON measured here are a few times higher than those observed in other locations from AMS measurements (typically $1-3 \%$ ) (Xu et al.,
2014), likely for the following reasons. First, previous studies were online measurements on non-refractory submicron aerosols, while it is likely that the supermicron fine particles $(1-2.5 \mu \mathrm{m})$ contain significant nitrogen-containing species, as observed before for marine aerosols (Violaki and Mihalopoulos, 2010). Secondly, we measured only the water-soluble fraction of OA, which may concentrate more nitrogen-containing species (partially from aqueous-phase processing). Thirdly, a recent study reveals that fossil fuel combustion-related emission can be a dominant source of ammonia in urban areas (Pan et al., 2016); it thus can act 

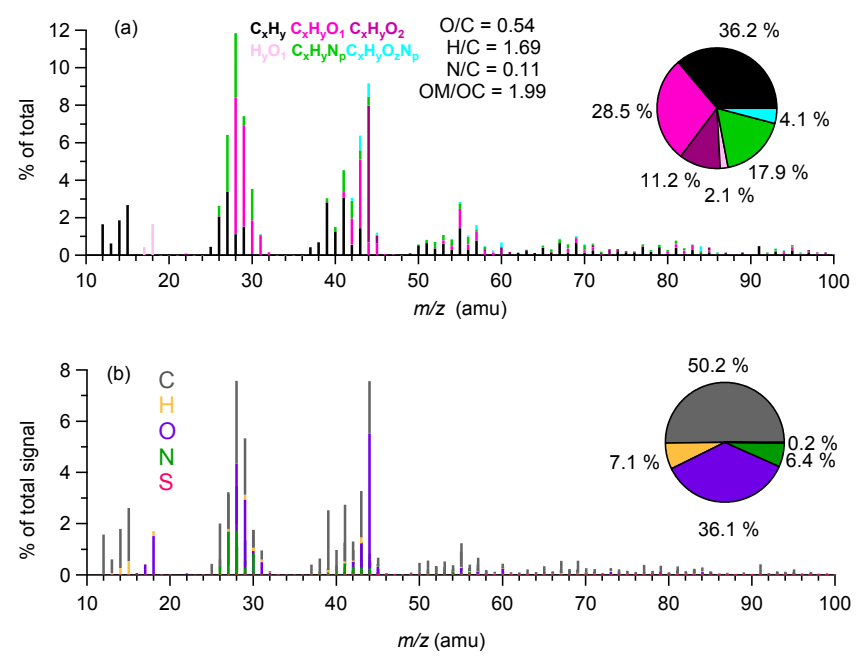

Figure 9. (a) High-resolution mass spectral profile of the WSOA measured by the SP-AMS (the mass spectrum is classified and colored by six ion families; the pie chart shows the mass contributions of each ion family to the total MS). (b) Average mass spectrum classified by five elements $(\mathrm{C}, \mathrm{H}, \mathrm{O}, \mathrm{N}$, and $\mathrm{S}$ ) (the inset pie chart shows mass contributions of the five elements, respectively).

as a significant contributor to amines, as amines are often co-emitted with ammonia (Ge et al., 2011b); these amines can be neutralized by inorganic or organic acids and, since aminium salts are highly hygroscopic (Ge et al., 2011a), they might be enriched in the WSOA and generate significant $\mathrm{C}_{x} \mathrm{H}_{y} \mathrm{~N}_{p}^{+}$ions. Nevertheless, more AMS analyses on the water-extracted $\mathrm{PM}_{2.5}$ samples collected from other locations should be conducted to further verify the abundance of ON species in the AMS mass spectra of the WSOA.

Overall, the average elemental ratios of the WSOA are 0.54 for $\mathrm{O} / \mathrm{C}, 1.69$ for $\mathrm{H} / \mathrm{C}, 0.11$ for $\mathrm{N} / \mathrm{C}$, and 1.99 for OM / OC (Fig. 9a). WSOA is on average comprised of $50.2 \% \mathrm{C}, 7.1 \% \mathrm{H}, 36.1 \% \mathrm{O}, 6.4 \% \mathrm{~N}$, and a negligible fraction $(0.2 \%)$ of S (Fig. $9 b)$.

\subsubsection{WSOA sources from PMF analysis}

The PMF analysis of the WSOA HRMS matrix identified four OA factors - including two primary OA (POA) factors, named nitrogen-enriched hydrocarbon-like OA (NHOA) and local primary OA (LOA), and two secondary OA factors, which are a less oxidized oxygenated OA (LO-OOA) and a more oxidized oxygenated OA (MO-OOA), as shown in Fig. 10.

The NHOA factor had a low $\mathrm{O} / \mathrm{C}$ ratio $(0.19)$ and was abundant in $\mathrm{C}_{x} \mathrm{H}_{y}^{+}$ions $(33.8 \%)$, and the NHOA time series also varied closely with those ions, representing its features as traffic-related OA. In particular, the factor was rich in $\mathrm{C}_{x} \mathrm{H}_{y} \mathrm{~N}_{p}^{+}$ions (43.1\%); as a result, it shows a much higher $\mathrm{N} / \mathrm{C}$ ratio $(0.26$, Fig. 10a) than other factors, and correlated well with $\mathrm{CHN}^{+}(r=0.91), \mathrm{CH}_{4} \mathrm{~N}^{+}(r=0.95)$,
$\mathrm{CH}_{2} \mathrm{~N}^{+}(r=0.85)$, and $\mathrm{C}_{2} \mathrm{H}_{4} \mathrm{~N}^{+}(r=0.87)$ (Fig. 10b). The N-containing ions in the NHOA MS were dominated by the reduced ions $\left(\mathrm{C}_{x} \mathrm{H}_{y} \mathrm{~N}^{+}\right)$rather than oxidized ones $\left(\mathrm{C}_{x} \mathrm{H}_{y} \mathrm{O}_{z} \mathrm{~N}^{+}\right)$, suggesting that amino compounds were likely the major ON species, and were inconsistent with our hypothesis aforementioned in Sect. 3.6.1 that they were mainly from fossil fuel combustion emissions. Nevertheless, future studies should be conducted to investigate in detail the contribution of fossil fuel combustion to the atmospheric ON species.

Another primary OA factor was defined as a local primary OA (LOA) which contains contributions from mixed anthropogenic emissions, such as cooking and coal combustion. LOA had a low $\mathrm{O} / \mathrm{C}$ ratio of 0.19 and also contained mainly reduced $\mathrm{C}_{x} \mathrm{H}_{y}^{+}$ions $(60.8 \%)$, verifying its primary origin. Note that its mass profile is characterized by peaks at $m / z 55$ (significant $\mathrm{C}_{3} \mathrm{H}_{3} \mathrm{O}^{+}$) and $m / z 57$ (significant $\mathrm{C}_{3} \mathrm{H}_{5} \mathrm{O}^{+}$). The abundance of $\mathrm{C}_{3} \mathrm{H}_{3} \mathrm{O}^{+}$at $m / z 55$ and $\mathrm{C}_{3} \mathrm{H}_{5} \mathrm{O}^{+}$at $m / z 57$ is a spectral feature of cooking $\mathrm{OA}$, and the overall COA MS and $\mathrm{O} / \mathrm{C}$ ratios are also similar to the COA factors reported in other studies, such as in Beijing. The LOA time series also correlated well with other cookingrelated marker ions, such as $\mathrm{C}_{5} \mathrm{H}_{8} \mathrm{O}^{+}(r=0.76), \mathrm{C}_{6} \mathrm{H}_{10} \mathrm{O}^{+}$ $(r=0.74)$, and $\mathrm{C}_{7} \mathrm{H}_{12} \mathrm{O}^{+}(r=0.67)$, consistent with the cooking OA from many previous studies (e.g., Y.-L. Sun et al., 2011; Ge et al., 2012a). All these results indicate that the LOA may have significant contributions from cooking activities. However, the ratio of LOA $/ \mathrm{C}_{6} \mathrm{H}_{10} \mathrm{O}^{+}(622.0)$ in this study was much higher than that obtained in winter in Fresno and New York City $(\sim 180)$, and its mass fraction to the total OA was also a few times higher than previous results, suggesting that it contains species from other primary sources rather than only cooking emissions.

The LO-OOA MS profile exhibited characteristics of oxidized OA, with enhanced signals at $m / z 29\left(\mathrm{CHO}^{+}\right)$and $m / z 43$ (mainly $\mathrm{C}_{2} \mathrm{H}_{3} \mathrm{O}^{+}$) and other oxygenated ions. Tight correlations between time series of LO-OOA and $\mathrm{CHO}^{+}(r=$ $0.92)$, and $\mathrm{C}_{2} \mathrm{H}_{3} \mathrm{O}^{+}(r=0.73)$, were also observed. Moreover, we also noticed relatively high signals of the BBOA tracer ions $\mathrm{C}_{2} \mathrm{H}_{4} \mathrm{O}_{2}^{+}$and $\mathrm{C}_{3} \mathrm{H}_{5} \mathrm{O}_{2}^{+}$in the LO-OOA MS, and found good correlations between LO-OOA and BBOA tracers $\left(r=0.87\right.$ with $\mathrm{C}_{2} \mathrm{H}_{4} \mathrm{O}_{2}^{+}$and $r=0.93$ with $\left.\mathrm{C}_{3} \mathrm{H}_{5} \mathrm{O}_{2}^{+}\right)$, indicating the possible influence of biomass burning. Thus, we compared the mass fraction of LO-OOA to total OA in different seasons, assuming that LO-OOA contributions would increase in straw-burning seasons given that it could be influenced by BBOA. Figure S6 showed the mass fractions of four factors during the straw-burning seasons (spring, summer) and the non-straw burning seasons (fall, winter). No obvious difference for the LO-OOA fraction was found. Furthermore, the $\mathrm{O} / \mathrm{C}$ and $\mathrm{OM} / \mathrm{OC}$ ratios were 0.53 and 1.95 , corresponding to 0.34 and 1.62 if calculated by using the method of Aiken et al. (2008), well within the O / C range of less-oxidized OA factors identified in other studies (Jimenez 

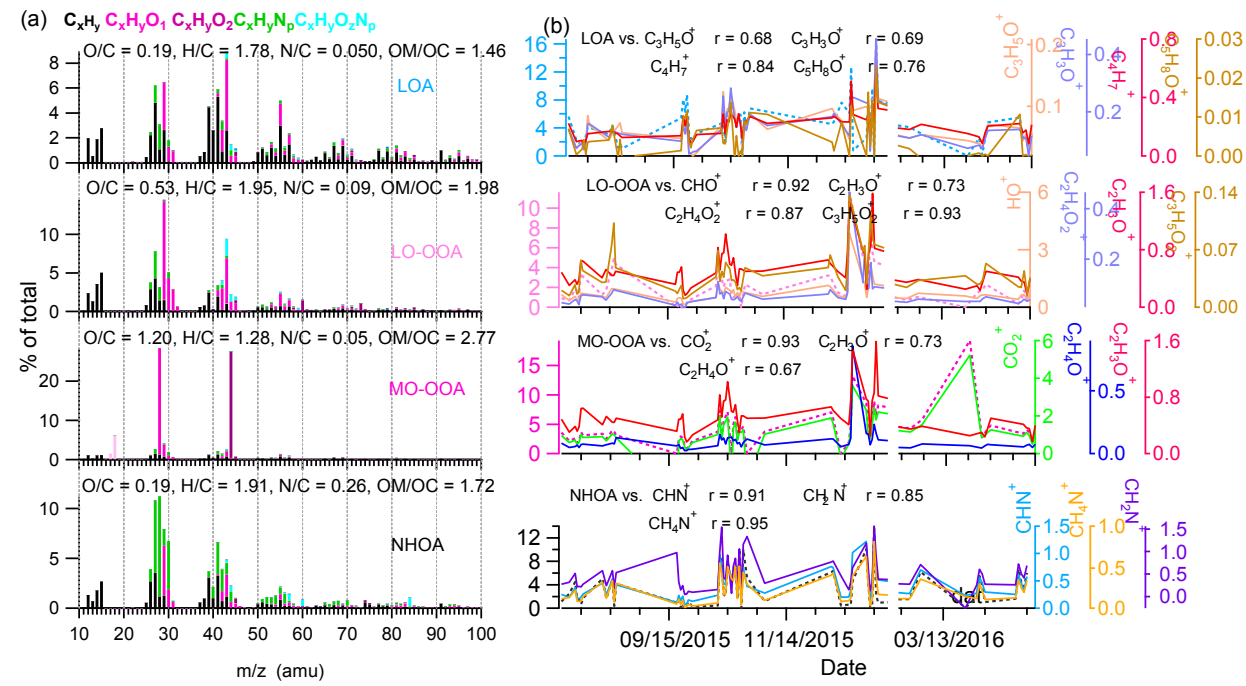

Figure 10. (a) High-resolution mass spectra of nitrogen-enriched hydrocarbon-like OA (NHOA), local primary OA (LOA), less-oxidized OA (LO-OOA), and more-oxidized OA (MO-OOA) separated by the PMF analyses, colored by six ion categories; (b) time series of the four WSOA factors, and corresponding tracer ions.

et al., 2009), but beyond the $\mathrm{O} / \mathrm{C}$ range of typical BBOA (0.18-0.26) (He et al., 2010).

The MO-OOA factor had prominent peaks at $m / z 28$ (mainly $\mathrm{CO}^{+}$) and $m / z 44$ (mainly $\mathrm{CO}_{2}^{+}$), and was dominated by $\mathrm{C}_{x} \mathrm{H}_{y} \mathrm{O}_{1}^{+}(36.6 \%)$ and $\mathrm{C}_{x} \mathrm{H}_{y} \mathrm{O}_{2}^{+}$ions $(29.0 \%)$ (Fig. 10a). As a result, MO-OOA had a very high $\mathrm{O} / \mathrm{C}$ ratio of 1.20 , showing that it is a heavily aged and processed $\mathrm{OA}$ component. Correspondingly, its time series correlated well with the secondary OA tracer ions, such as $\mathrm{CO}_{2}^{+}(r=0.93)$, $\mathrm{C}_{2} \mathrm{H}_{4} \mathrm{O}^{+}(r=0.67)$, and $\mathrm{C}_{2} \mathrm{H}_{3} \mathrm{O}^{+}(r=0.73)$ (Fig. 10b).

The $f_{44}$ (mass fraction of $m / z 44$ to the total OA) vs. $f_{43}$ (mass fraction of $m / z 43$ to the total $\mathrm{OA}$, defined by $\mathrm{Ng}$ et al., 2010) can be used to investigate the degree of oxygenation of the identified factors. As presented in Fig. 11a, apart from NHOA, another three factors (LOA, LO-OOA, and MO-OOA) all fall within the triangular region. MOOOA is located in the upper position with a higher $f_{44}$ of 0.28 , while LO-OOA is located in the lower position of the plot, as it had a high fraction of $f_{43}(0.09)$. This distribution of the four factors is also consistent with other studies.

The mass contributions of the four factors to total WSOA over the whole year are $23.9 \%$ for NHOA, $31.2 \%$ for LOA, $15.3 \%$ for LO-OOA and $29.7 \%$ for MO-OOA (Fig. 11b). POA (= NHOA + LOA $)$ overweighed SOA (= LO-OOA + MO-OOA) mass, showing the dominant role of local anthropogenic emissions in the aerosol pollution in Changzhou, similar to that observed in Nanjing (J. Wang et al., 2016a). However, during spring and winter, SOA contributions dominated over POA, indicating significant SOA formation, in particular the MO-OOA during cold seasons, which is in agreement with the OC / EC results.

\subsection{Back trajectory clustering analysis}

The Hybrid Single-particle Lagrangian Integrated Trajectory (HYSPLIT) model (Draxler et al., 2012) was used to investigate the origins of air masses based on the meteorological data available at the National Oceanic and Atmospheric Administration (NOAA) Global Data Assimilation System (GDAS). The $72 \mathrm{~h}$ back trajectories of air parcels at $100 \mathrm{~m}$ above ground level in Changzhou were calculated at 08:00 local time (LT) throughout the campaign, and the results were presented in Fig. 12. The four-, five-, four-, and fourcluster solutions were adopted for spring, summer, fall, and winter, respectively. During summer, air masses from the southeasterly, easterly, and westerly directions, passing over Anhui and Jiangxi provinces and Shanghai, dominated the trajectories' (75\%) air masses. Westerly and northwesterly air parcels dominated during winter, which may intercept air pollutants from Mongolia, Beijing and Shandong Province. Considering the relatively short sampling days in each season, a more detailed discussion that is useful for distinguishing contributions of local, regional, and long-range transport to the air pollution will be the subject of our future work.

\section{Conclusions}

We presented here the comprehensive characterization results on the $\mathrm{PM}_{2.5}$ samples collected across nearly 1 year in Changzhou, located in the YRD region of China. The species we quantified, including WSIIs, trace metals, EC, WSOA, WIOA, and also PAHs, can reproduce on average $\sim 80 \%$ of the mass of the $\mathrm{PM}_{2.5}\left(108.3 \mu \mathrm{g} \mathrm{m}^{-3}\right)$. WSIIs were the major component, accounting for $52.1 \%$ of $\mathrm{PM}_{2.5}$ mass, and 

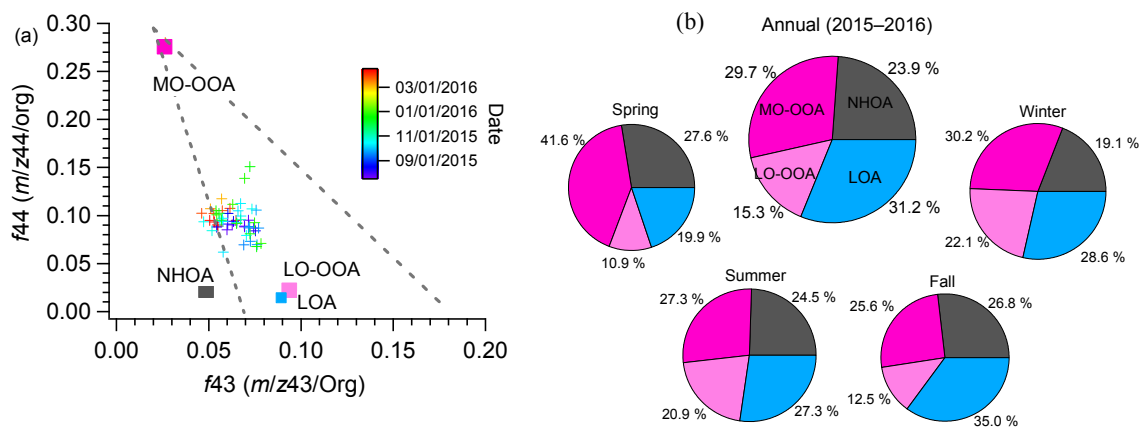

Figure 11. (a) Triangle plot of $f_{44}$ vs. $f_{43}$ for all WSOA, and the four WSOA factors identified by the PMF analyses; (b) pie charts of the mass contributions of four WSOA factors to the total WSOA in four seasons and the whole sampling period.
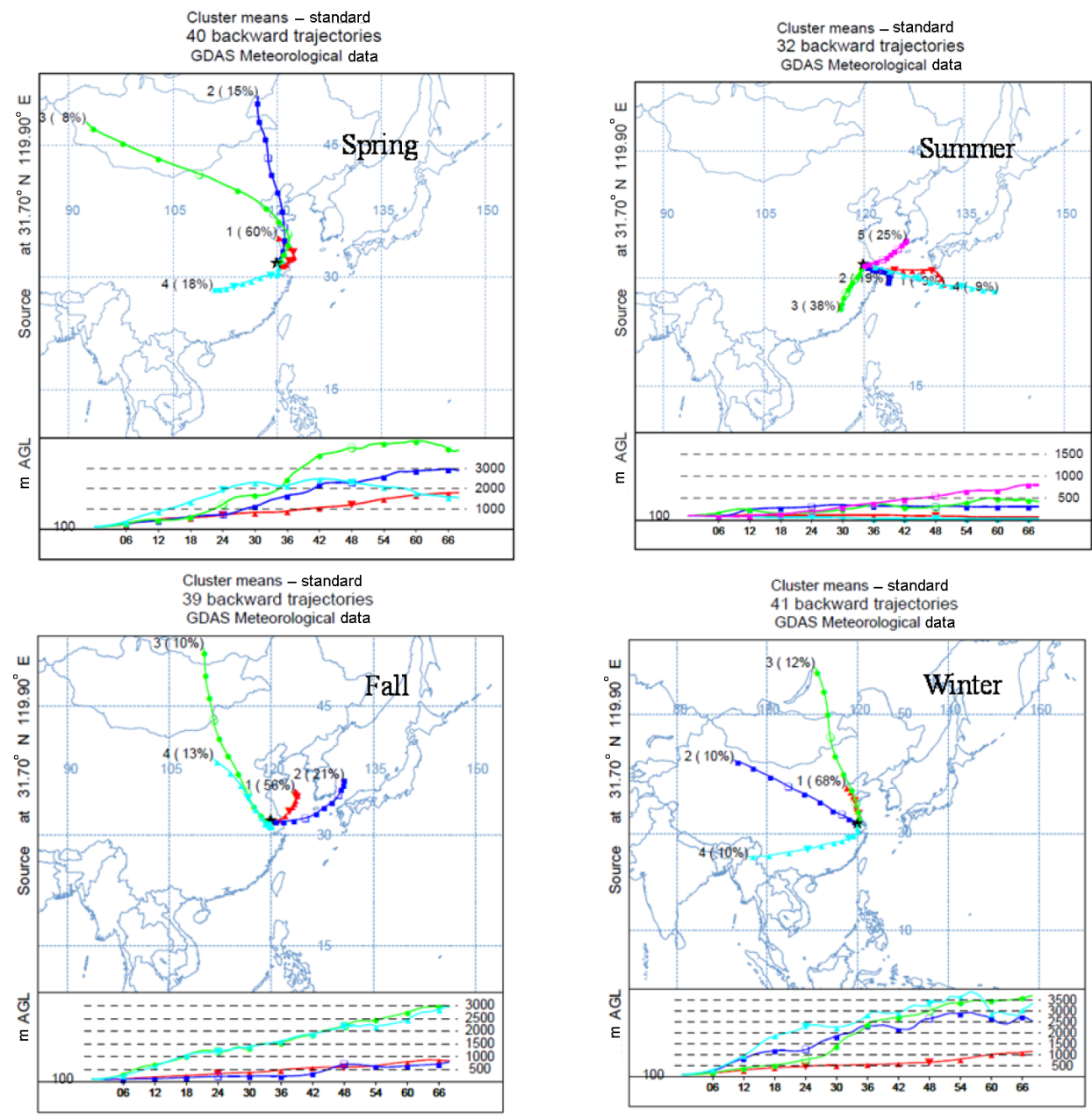

Figure 12. Air mass back trajectories across four seasons during the sampling period.

$\mathrm{NO}_{3}^{-}, \mathrm{SO}_{4}^{2-}$, and $\mathrm{NH}_{4}^{+}$were the three most abundant ions. The organic matter (the sum of WSOA and WIOA) occupied $21.5 \%$ of $\mathrm{PM}_{2.5}$ mass, and EC accounted for $\sim 5 \%$ of $\mathrm{PM}_{2.5}$ mass. Trace metal elements accounted for $\sim 5$ and $\sim 2.7 \%$ of $\mathrm{PM}_{2.5}$ mass during winter and spring. Total PAH concentrations were found to be at a relatively high concentration of $140.25 \mathrm{ng} \mathrm{m}^{-3}$ in winter, above 3 times the average mass loading of $41.42 \mathrm{ng} \mathrm{m}^{-3}$ in spring, both with InP, BghiP, and $\mathrm{Chr}$ as the three most abundant PAHs. The average mass ratio of $\mathrm{NO}_{3}^{-} / \mathrm{SO}_{4}^{2-}$ was 1.21 , suggesting a significant role of traffic emissions, which is consistent with the source analysis results based on the diagnostic ratios of the selected PAHs 
(BaP / BghiP, Flua / (Flua+Pyr), and $\mathrm{BaP} /(\mathrm{BaP}+\mathrm{Chr}))$. In addition, a high $\mathrm{Cl}^{-} / \mathrm{Na}^{+}$ratio and the diagnostic ratio of Phe / (Ant+Phe) also indicated a contribution from coal combustion, in particular during winter.

In order to obtain further information regarding the particle source, we analyzed the WSOA using SP-AMS and conducted PMF analyses of the HRMS of WSOA. Four OA factors, including NHOA, LOA, LO-OOA, and MO-OOA, were identified. The mean mass contribution of POA was larger than that of SOA, revealing that local anthropogenic activities are the major drivers of PM pollution in Changzhou. Nevertheless, during cold seasons, SOA mass contribution increased, indicating a significant role of secondarily formed species as well; thus, reduction of air pollution in Changzhou should focus on the strict emission control of both primary particles and the gaseous secondary aerosol precursors. One interesting finding in this work is the enrichment of organic nitrogen species in WSOA, and source analysis indicates that traffic emissions can be a significant contributor to these species, which warrants more detailed investigations in the future. Also, more offline samples should be collected to achieve a more robust PMF analysis. Simultaneous online AMS measurement of the fine particles and measurements of gaseous species $\left(\mathrm{SO}_{2}, \mathrm{NO}_{2}, \mathrm{O}_{3}, \mathrm{CO}\right.$ and some volatile organic compounds) are also essential to better understand the aerosol characteristics and to implement proper measures to abate the air pollution in this region.

\section{Data availability}

The data presented in this study are available from the authors upon request (bess_ye@jsut.edu.cn and caxinra@163.com).

\section{The Supplement related to this article is available online at doi:10.5194/acp-17-2573-2017-supplement.}

Competing interests. The authors declare that they have no conflict of interest.

Acknowledgements. This work was supported by the Natural Science Foundation of China (grant nos. 21407079 and 91544220), the Jiangsu National Science Foundation (BK20150042), the Specially-Appointed Professors Foundation and Jiangsu Innovation and Entrepreneurship Program (for Xinlei Ge), and the Major Research Development Program of Jiangsu Province (BE2016657 and BY2016030-15). We would also like to acknowledge Gang Li from the Chinese Academy of Science for providing us with the OC / EC measurements.

Edited by: A. Ding

Reviewed by: two anonymous referees

\section{References}

Aiken, A. C., Decarlo, P. F., Kroll, J. H., Worsnop, D. R., Huffman, J. A., Docherty, K. S., Ulbrich, I. M., Mohr, C., Kimmel, J. R., Sueper, D., Sun, Y., Zhang, Q., Trimborn, A., Northway, M., Ziemann, P. J., Canagaratna, M. R., Onasch, T. B., Alfarra, M. R., Prevot, A. S. H., Dommen, J., Duplissy, J., Metzger, A., Baltensperger, U., and Jimenez, J. L.: O/C and OM/OC ratios of primary, secondary, and ambient organic aerosols with highresolution time-of-flight aerosol mass spectrometry, Environ. Sci. Technol., 42, 4478-4485, doi:10.1021/Es703009q, 2008.

Anderson, J. O., Thundiyil, J. G., and Stolbach, A.: Clearing the air: A review of the effects of particulate matter air pollution on human health, J. Med. Toxicol., 8, 166-175, doi:10.1007/s13181011-0203-1, 2012.

Arimoto, R., Duce, R. A., Savoie, D. L., Prospero, J. M., Talbot, R., Cullen, J. D., Tomza, U., Lewis, N. F., and Ray, B. J.: Relationships among aerosol constituents from Asia and the North Pacific during PEM-West A, J. Geophys. Res.-Atmos., 101, 2011-2023, doi:10.1029/95JD01071, 1996.

Bozzetti, C., Sosedova, Y., Xiao, M., Daellenbach, K. R., Ulevicius, V., Dudoitis, V., Mordas, G., Bycenkiene, S., Plauškaite, K., Vlachou, A., Golly, B., Chazeau, B., Besombes, J.-L., Baltensperger, U., Jaffrezo, J.-L., Slowik, J. G., El Haddad, I., and Prévôt, A. S. H.: Argon offline-AMS source apportionment of organic aerosol over yearly cycles for an urban, rural, and marine site in northern Europe, Atmos. Chem. Phys., 17, 117-141, doi:10.5194/acp-17117-2017, 2017.

Canagaratna, M. R., Jayne, J. T., Jimenez, J. L., Allan, J. D., Alfarra, M. R., Zhang, Q., Onasch, T. B., Drewnick, F., Coe, H., Middlebrook, A., Delia, A., Williams, L. R., Trimborn, A. M., Northway, M. J., DeCarlo, P. F., Kolb, C. E., Davidovits, P., and Worsnop, D. R.: Chemical and microphysical characterization of ambient aerosols with the aerodyne aerosol mass spectrometer, Mass Spectrom. Rev., 26, 185-222, doi:10.1002/Mas.20115, 2007.

Canagaratna, M. R., Jimenez, J. L., Kroll, J. H., Chen, Q., Kessler, S. H., Massoli, P., Hildebrandt Ruiz, L., Fortner, E., Williams, L. R., Wilson, K. R., Surratt, J. D., Donahue, N. M., Jayne, J. T., and Worsnop, D. R.: Elemental ratio measurements of organic compounds using aerosol mass spectrometry: characterization, improved calibration, and implications, Atmos. Chem. Phys., 15, 253-272, doi:10.5194/acp-15-253-2015, 2015.

Cao, J. J., Xu, H. M., Xu, Q., Chen, B. H., and Kan, H. D.: Fine particulate matter constituents and cardiopulmonary mortality in a heavily polluted Chinese city, Environ. Health Persp., 120, 373 378, doi:10.1289/ehp.1103671, 2012.

Cheng, Y., He, K. B., Du, Z. Y., Zheng, M., Duan, F. K., and Ma, Y. L.: Humidity plays an important role in the $\mathrm{PM}_{2.5}$ pollution in Beijing, Environ. Pollut., 197, 68-75, doi:10.1016/j.envpol.2014.11.028, 2015.

Chow, J. C., Watson, J. G., Chen, L. W. A., Arnott, W. P., Moosmüller, H., and Fung, K.: Equivalence of elemental carbon by thermal/optical reflectance and transmittance with different temperature protocols, Environ. Sci. Technol., 38, 4414-4422, doi:10.1021/es034936u, 2004.

Chow, J. C., Watson, J. G., Louie, P. K., Chen, L. W., and Sin, D.: Comparison of $\mathrm{PM}_{2.5}$ carbon measurement methods in Hong Kong, China, Environ. Pollut., 137, 334-344, doi:10.1016/j.envpol.2005.01.006, 2005. 
Daellenbach, K. R., Bozzetti, C., Krepelová, A., Canonaco, F., Wolf, R., Zotter, P., Fermo, P., Crippa, M., Slowik, J. G., Sosedova, Y., Zhang, Y., Huang, R.-J., Poulain, L., Szidat, S., Baltensperger, U., El Haddad, I., and Prévôt, A. S. H.: Characterization and source apportionment of organic aerosol using offline aerosol mass spectrometry, Atmos. Meas. Tech., 9, 23-39, doi:10.5194/amt-9-23-2016, 2016

Ding, A. J., Fu, C. B., Yang, X. Q., Sun, J. N., Zheng, L. F., Xie, Y. N., Herrmann, E., Nie, W., Petäjä, T., Kerminen, V.-M., and Kulmala, M.: Ozone and fine particle in the western Yangtze River Delta: an overview of $1 \mathrm{yr}$ data at the SORPES station, Atmos. Chem. Phys., 13, 5813-5830, doi:10.5194/acp-13-58132013, 2013.

Draxler, R., Stunder, B., Rolph, G., Stein, A., and Taylor, A.: HYSPLIT4 user's guide, version 4, report, NOAA, Silver Spring, MD, 2012.

Drewnick, F.: Speciation analysis in on-line aerosol mass spectrometry, Anal. Bioanal. Chem., 404, 2127-2131, doi:10.1007/s00216-012-6295-x, 2012.

Duan, F., Liu, X., He, K., and Dong, S.: Measurements and characteristics of nitrogen-containing compounds in atmospheric particulate matter in Beijing, China, B. Environ. Contam. Tox., 82, 332-337, doi:10.1007/s00128-008-9560-0, 2009.

Duan, J., Tan, J., Wang, S., Chai, F., He, K., and Hao, J.: Roadside, urban, and rural comparison of size distribution characteristics of PAHs and carbonaceous components of Beijing, China, J. Atmos. Chem., 69, 337-349, doi:10.1007/s10874-012-9242-5, 2012.

Dzepina, K., Arey, J., Marr, L. C., Worsnop, D. R., Salcedo, D., Zhang, Q., Onasch, T. B., Molina, L. T., Molina, M. J., and Jimenez, J. L.: Detection of particle-phase polycyclic aromatic hydrocarbons in Mexico City using an aerosol mass spectrometer, Int. J. Mass Spectrom., 263, 152-170, doi:10.1016/j.ijms.2007.01.010, 2007.

Fan, J., Yue, X., Jing, Y., Chen, Q., and Wang, S.: Online monitoring of water-soluble ionic composition of $\mathrm{PM}_{10}$ during early summer over Lanzhou City, J. Environ. Sci., 26, 353-361, doi:10.1016/s1001-0742(13)60431-3, 2014.

Feng, J., Hu, J., Xu, B., Hu, X., Sun, P., Han, W., Gu, Z., Yu, $\mathrm{X}$., and $\mathrm{Wu}, \mathrm{M}$.: Characteristics and seasonal variation of organic matter in $\mathrm{PM}_{2.5}$ at a regional background site of the Yangtze River Delta region, China, Atmos. Environ., 123, 288297, doi:10.1016/j.atmosenv.2015.08.019, 2015

Feng, Y., Chen, Y., Guo, H., Zhi, G., Xiong, S., Li, J., Sheng, G., and $\mathrm{Fu}, \mathrm{J}$. : Characteristics of organic and elemental carbon in $\mathrm{PM}_{2.5}$ samples in Shanghai, China, Atmos. Res., 92, 434-442, doi:10.1016/j.atmosres.2009.01.003, 2009.

Fu, H., Zhang, M., Li, W., Chen, J., Wang, L., Quan, X., and Wang, W.: Morphology, composition and mixing state of individual carbonaceous aerosol in urban Shanghai, Atmos. Chem. Phys., 12, 693-707, doi:10.5194/acp-12-693-2012, 2012.

Ge, X., Wexler, A. S., and Clegg, S. L.: Atmospheric amines - Part II. Thermodynamic properties and gas/particle partitioning, Atmos. Environ., 45, 561-577, doi:10.1016/j.atmosenv.2010.10.013, 2011a.

Ge, X., Wexler, A. S., and Clegg, S. L.: Atmospheric amines - Part I. A review, Atmos. Environ., 45, 524-546, doi:10.1016/j.atmosenv.2010.10.012, 2011b.

Ge, X., Setyan, A., Sun, Y., and Zhang, Q.: Primary and secondary organic aerosols in Fresno, California during wintertime: Results from high resolution aerosol mass spectrometry, J. Geophys. Res.-Atmos., 117, D19301, doi:10.1029/2012jd018026, 2012a.

Ge, X., Zhang, Q., Sun, Y., Ruehl, C. R., and Setyan, A.: Effect of aqueous-phase processing on aerosol chemistry and size distributions in Fresno, California, during wintertime, Environ. Chem., 9, 221-235, doi:10.1071/EN11168, 2012b.

Ge, X., Shaw, S. L., and Zhang, Q.: Toward understanding amines and their degradation products from postcombustion $\mathrm{CO}_{2}$ capture processes with aerosol mass spectrometry, Environ. Sci. Technol., 48, 5066-5075, doi:10.1021/es4056966, 2014.

Ge, X., Wang, J., Zhang, Z., Wang, X., and Chen, M.: Thermodynamic modeling of electrolyte solutions by a hybrid ioninteraction and solvation (HIS) model, Calphad, 48, 79-88, doi:10.1016/j.calphad.2014.11.001, 2015.

Gu, J., Bai, Z., Liu, A., Wu, L., Xie, Y., Li, W., Dong, H., and Zhang, $\mathrm{X}$.: Characterization of atmospheric organic carbon and element carbon of $\mathrm{PM}_{2.5}$ and $\mathrm{PM}_{10}$ at Tianjin, China, Aerosol Air Qual. Res., 10, 167-176, doi:10.4209/aaqr.2009.12.0080, 2010.

Gu, J., Du, S., Han, D., Hou, L., Yi, J., Xu, J., Liu, G., Han, B., Yang, G., and Bai, Z.-P.: Major chemical compositions, possible sources, and mass closure analysis of $\mathrm{PM}_{2.5}$ in Jinan, China, Air Qual. Atmos. Health, 7, 251-262, doi:10.1007/s11869-0130232-9, 2014.

He, J., Fan, S., Meng, Q., Sun, Y., Zhang, J., and Zu, F.: Polycyclic aromatic hydrocarbons (PAHs) associated with fine particulate matters in Nanjing, China: Distributions, sources and meteorological influences, Atmos. Environ., 89, 207-215, doi:10.1016/j.atmosenv.2014.02.042, 2014.

He, L.-Y., Lin, Y., Huang, X.-F., Guo, S., Xue, L., Su, Q., Hu, M., Luan, S.-J., and Zhang, Y.-H.: Characterization of highresolution aerosol mass spectra of primary organic aerosol emissions from Chinese cooking and biomass burning, Atmos. Chem. Phys., 10, 11535-11543, doi:10.5194/acp-10-11535-2010, 2010.

Heal, M. R., Kumar, P., and Harrison, R. M.: Particles, air quality, policy and health, Chem. Soc. Rev., 41, 6606-6630, doi:10.1039/C2CS35076A, 2012.

Ho, K. F., Ho, S. S. H., Huang, R.-J., Liu, S. X., Cao, J.-J., Zhang, T., Chuang, H.-C., Chan, C. S., Hu, D., and Tian, L.: Characteristics of water-soluble organic nitrogen in fine particulate matter in the continental area of China, Atmos. Environ., 106, 252-261, doi:10.1016/j.atmosenv.2015.02.010, 2015.

Hu, J., Ying, Q., Wang, Y., and Zhang, H.: Characterizing multi-pollutant air pollution in China: Comparison of three air quality indices, Environ. Int., 84, 17-25, doi:10.1016/j.envint.2015.06.014, 2015.

Hu, W., Hu, M., Hu, W., Jimenez, J. L., Yuan, B., Chen, W., Wang, M., Wu, Y., Chen, C., Wang, Z., Peng, J., Zeng, L., and Shao, M.: Chemical composition, sources, and aging process of submicron aerosols in Beijing: Contrast between summer and winter, J. Geophys. Res.-Atmos., 121, 2015JD024020, doi:10.1002/2015JD024020, 2016.

Hu, X., Zhang, Y., Ding, Z., Wang, T., Lian, H., Sun, Y., and $\mathrm{Wu}, \mathrm{J} .:$ Bioaccessibility and health risk of arsenic and heavy metals $(\mathrm{Cd}, \mathrm{Co}, \mathrm{Cr}, \mathrm{Cu}, \mathrm{Ni}, \mathrm{Pb}, \mathrm{Zn}$ and $\mathrm{Mn})$ in TSP and $\mathrm{PM}_{2.5}$ in Nanjing, China, Atmos. Environ., 57, 146-152, doi:10.1016/j.atmosenv.2012.04.056, 2012.

Huang, R., Zhang, Y., Bozzetti, C., Ho, K., Cao, J., Han, Y., Daellenbach, K. R., Slowik, J. G., Platt, S. M., Canonaco, F., Zotter, P., Wolf, R., Pieber, S. M., Bruns, E. A., Crippa, M., Ciarelli, 
G., Piazzalunga, A., Schwikowski, M., Abbaszade, G., SchnelleKreis, J., Zimmermann, R., An, Z., Szidat, S., Baltensperger, U., Haddad, I. E., and Prevot, A. S. H.: High secondary aerosol contribution to particulate pollution during haze events in China, Nature, 514, 218-222, doi:10.1038/nature13774, 2014.

Huang, T., Chen, J., Zhao, W., Cheng, J., and Cheng, S.: Seasonal variations and correlation analysis of water-soluble inorganic ions in $\mathrm{PM}_{2.5}$ in Wuhan, 2013, Atmosphere, 7, 49, doi:10.3390/atmos7040049, 2016.

Huang, X.-F., He, L.-Y., Hu, M., Canagaratna, M. R., Sun, Y., Zhang, Q., Zhu, T., Xue, L., Zeng, L.-W., Liu, X.-G., Zhang, Y.-H., Jayne, J. T., Ng, N. L., and Worsnop, D. R.: Highly time-resolved chemical characterization of atmospheric submicron particles during 2008 Beijing Olympic Games using an Aerodyne High-Resolution Aerosol Mass Spectrometer, Atmos. Chem. Phys., 10, 8933-8945, doi:10.5194/acp-10-8933-2010, 2010.

Jimenez, J. L., Canagaratna, M. R., Donahue, N. M., Prevot, A. S. H., Zhang, Q., Kroll, J. H., DeCarlo, P. F., Allan, J. D., Coe, H., Ng, N. L., Aiken, A. C., Docherty, K. S., Ulbrich, I. M., Grieshop, A. P., Robinson, A. L., Duplissy, J., Smith, J. D., Wilson, K. R., Lanz, V. A., Hueglin, C., Sun, Y. L., Tian, J., Laaksonen, A., Raatikainen, T., Rautiainen, J., Vaattovaara, P., Ehn, M., Kulmala, M., Tomlinson, J. M., Collins, D. R., Cubison, M. J., Dunlea, E. J., Huffman, J. A., Onasch, T. B., Alfarra, M. R., Williams, P. I., Bower, K., Kondo, Y., Schneider, J., Drewnick, F., Borrmann, S., Weimer, S., Demerjian, K., Salcedo, D., Cottrell, L., Griffin, R., Takami, A., Miyoshi, T., Hatakeyama, S., Shimono, A., Sun, J. Y., Zhang, Y. M., Dzepina, K., Kimmel, J. R., Sueper, D., Jayne, J. T., Herndon, S. C., Trimborn, A. M., Williams, L. R., Wood, E. C., Middlebrook, A. M., Kolb, C. E., Baltensperger, U., and Worsnop, D. R.: Evolution of organic aerosols in the atmosphere, Science, 326, 1525-1529, doi:10.1126/science.1180353, 2009.

Khalili, N. R., Scheff, P. A., and Holsen, T. M.: PAH source fingerprints for coke ovens, diesel and, gasoline engines, highway tunnels, and wood combustion emissions, Atmos. Environ., 29, 533-542, doi:10.1016/1352-2310(94)00275-P, 1995.

Kong, S., Ding, X., Bai, Z., Han, B., Chen, L., Shi, J., and $\mathrm{Li}, \mathrm{Z}$.: A seasonal study of polycyclic aromatic hydrocarbons in $\mathrm{PM}_{2.5}$ and $\mathrm{PM}_{2.5-10}$ in five typical cities of Liaoning Province, China, J. Hazard. Mater., 183, 70-80, doi:10.1016/j.jhazmat.2010.06.107, 2010.

Kong, S., Li, X., Li, L., Yin, Y., Chen, K., Yuan, L., Zhang, Y., Shan, Y., and Ji, Y.: Variation of polycyclic aromatic hydrocarbons in atmospheric $\mathrm{PM}_{2.5}$ during winter haze period around 2014 Chinese Spring Festival at Nanjing: Insights of source changes, air mass direction and firework particle injection, Sci. Total Environ., 520, 59-72, doi:10.1016/j.scitotenv.2015.03.001, 2015.

Kulmala, M., Lappalainen, H. K., Petäjä, T., Kurten, T., Kerminen, V. M., Viisanen, Y., Hari, P., Sorvari, S., Bäck, J., Bondur, V., Kasimov, N., Kotlyakov, V., Matvienko, G., Baklanov, A., Guo, H. D., Ding, A., Hansson, H. C., and Zilitinkevich, S.: Introduction: The Pan-Eurasian Experiment (PEEX) multidisciplinary, multiscale and multicomponent research and capacity-building initiative, Atmos. Chem. Phys., 15, 1308513096, doi:10.5194/acp-15-13085-2015, 2015.

Lee, A. K. Y., Willis, M. D., Healy, R. M., Onasch, T. B., and Abbatt, J. P. D.: Mixing state of carbonaceous aerosol in an urban environment: single particle characterization using the soot particle aerosol mass spectrometer (SP-AMS), Atmos. Chem. Phys., 15, 1823-1841, doi:10.5194/acp-15-1823-2015, 2015.

Li, B., Zhang, J., Zhao, Y., Yuan, S., Zhao, Q., Shen, G., and Wu, H.: Seasonal variation of urban carbonaceous aerosols in a typical city Nanjing in Yangtze River Delta, China, Atmos. Environ., 106, 223-231, doi:10.1016/j.atmosenv.2015.01.064, 2015.

Liu, G., Li, J., Wu, D., and Xu, H.: Chemical composition and source apportionment of the ambient PM2.5 in Hangzhou, China, Particuology, 18, 135-143, doi:10.1016/j.partic.2014.03.011, 2015.

Meng, C. C., Wang, L. T., Zhang, F. F., Wei, Z., Ma, S. M., Ma, X., and Yang, J.: Characteristics of concentrations and water-soluble inorganic ions in $\mathrm{PM}_{2.5}$ in Handan City, Hebei province, China, Atmos. Res., 171, 133-146, doi:10.1016/j.atmosres.2015.12.013, 2016.

Mihara, T. and Mochida, M.: Characterization of SolventExtractable Organics in Urban Aerosols Based on Mass Spectrum Analysis and Hygroscopic Growth Measurement, Environ. Sci. Technol., 45, 9168-9174, doi:10.1021/es201271w, 2011.

Mirante, F., Salvador, P., Pio, C., Alves, C., Artiñano, B., Caseiro, A., and Revuelta, M. A.: Size fractionated aerosol composition at roadside and background environments in the Madrid urban atmosphere, Atmos. Res., 138, 278-292, doi:10.1016/j.atmosres.2013.11.024, 2014.

Ng, N. L., Canagaratna, M. R., Zhang, Q., Jimenez, J. L., Tian, J., Ulbrich, I. M., Kroll, J. H., Docherty, K. S., Chhabra, P S., Bahreini, R., Murphy, S. M., Seinfeld, J. H., Hildebrandt, L., Donahue, N. M., DeCarlo, P. F., Lanz, V. A., Prévôt, A. S. H., Dinar, E., Rudich, Y., and Worsnop, D. R.: Organic aerosol components observed in Northern Hemispheric datasets from Aerosol Mass Spectrometry, Atmos. Chem. Phys., 10, 46254641, doi:10.5194/acp-10-4625-2010, 2010.

Ng, N. L., Canagaratna, M. R., Jimenez, J. L., Zhang, Q., Ulbrich, I. M., and Worsnop, D. R.: Real-time methods for estimating organic component mass concentrations from aerosol mass spectrometer data, Environ. Sci. Technol., 45, 910-916, doi:10.1021/Es102951k, 2011.

Onasch, T. B., Trimborn, A., Fortner, E. C., Jayne, J. T., Kok, G. L., Williams, L. R., Davidovits, P., and Worsnop, D. R.: Soot particle aerosol mass spectrometer: Development, validation, and initial application, Aerosol Sci. Tech., 46, 804-817, doi:10.1080/02786826.2012.663948, 2012.

Pan, Y., Tian, S., Liu, D., Fang, Y., Zhu, X., Zhang, Q., Zheng, B., Michalski, G., and Wang, Y.: Fossil Fuel Combustion-Related Emissions Dominate Atmospheric Ammonia Sources during Severe Haze Episodes: Evidence from 15N-Stable Isotope in SizeResolved Aerosol Ammonium, Environ. Sci. Technol., 50, 80498056, doi:10.1021/acs.est.6b00634, 2016.

Qi, L., Chen, M., Ge, X., Zhang, Y., and Guo, B.: Seasonal variations and sources of 17 aerosol metal elements in suburban Nanjing, China, Atmosphere, 7, 153, 2016a.

Qi, L., Zhang, Y., Ma, Y., Chen, M., Ge, X., Ma, Y., Zheng, J., Wang, Z., and Li, S.: Source identification of trace elements in the atmosphere during the second Asian Youth Games in Nanjing, China: Influence of control measures on air quality, Atmos. Pollut. Res., 7, 547-556, doi:10.1016/j.apr.2016.01.003, 2016 b.

Qiao, T., Zhao, M., Xiu, G., and Yu, J.: Seasonal variations of water soluble composition (WSOC, Hulis and WSIIs) in $\mathrm{PM}_{1}$ and its 
implications on haze pollution in urban Shanghai, China, Atmos. Environ., 123, 306-314, doi:10.1016/j.atmosenv.2015.03.010, 2015.

Saldarriaga-Noreña, H., López-Márquez, R., Murillo-Tovar, M., Hernández-Mena, L., Ospina-Noreña, E., Sánchez-Salinas, E., Waliszewski, S., and Montiel-Palma, S.: Analysis of PAHs associated with particulate matter $\mathrm{PM}_{2.5}$ in two places at the city of Cuernavaca, Morelos, México, Atmosphere, 6, 1259-1270, doi:10.3390/atmos6091259, 2015.

Shen, G. F., Yuan, S. Y., Xie, Y. N., Xia, S. J., Li, L., Yao, Y. K., Qiao, Y. Z., Zhang, J., Zhao, Q. Y., Ding, A. J., Li, B., and Wu, H. S.: Ambient levels and temporal variations of $\mathrm{PM}_{2.5}$ and $\mathrm{PM}_{10}$ at a residential site in the mega-city, Nanjing, in the western Yangtze River Delta, China, J. Environ. Sci. Heal. A, 49, 171178, doi:10.1080/10934529.2013.838851, 2014.

Shi, J., Gao, H., Qi, J., Zhang, J., and Yao, X.: Sources, compositions, and distributions of water-soluble organic nitrogen in aerosols over the China Sea, J. Geophys. Res.-Atmos., 115, D17303, doi:10.1029/2009jd013238, 2010.

Sun, Y., Zhang, Q., Zheng, M., Ding, X., Edgerton, E. S., and Wang, $\mathrm{X}$.: Characterization and source apportionment of water-soluble organic matter in atmospheric fine particles $\left(\mathrm{PM}_{2.5}\right)$ with highresolution aerosol mass spectrometry and GC-MS, Environ. Sci. Technol., 45, 4854-4861, doi:10.1021/es200162h, 2011.

Sun, Y., Jiang, Q., Wang, Z., Fu, P., Li, J., Yang, T., and Yin, Y.: Investigation of the sources and evolution processes of severe haze pollution in Beijing in January 2013, J. Geophys. Res.-Atmos., 119, 4380-4398, doi:10.1002/2014jd021641, 2014.

Sun, Y., Du, W., Fu, P., Wang, Q., Li, J., Ge, X., Zhang, Q., Zhu, C., Ren, L., Xu, W., Zhao, J., Han, T., Worsnop, D. R., and Wang, Z.: Primary and secondary aerosols in Beijing in winter: sources, variations and processes, Atmos. Chem. Phys., 16, 8309-8329, doi:10.5194/acp-16-8309-2016, 2016.

Sun, Y.-L., Zhang, Q., Schwab, J. J., Demerjian, K. L., Chen, W.N., Bae, M.-S., Hung, H.-M., Hogrefe, O., Frank, B., Rattigan, O. V., and Lin, Y.-C.: Characterization of the sources and processes of organic and inorganic aerosols in New York city with a high-resolution time-of-flight aerosol mass apectrometer, Atmos. Chem. Phys., 11, 1581-1602, doi:10.5194/acp-11-15812011, 2011.

Szabó, J., Nagy, A. S., and Erdős, J.: Ambient concentrations of $\mathrm{PM}_{10}, \mathrm{PM}_{10}$-bound polycyclic aromatic hydrocarbons and heavy metals in an urban site of Győr, Hungary, Air Qual. Atmos. Health, 8, 229-241, doi:10.1007/s11869-015-0318-7, 2015.

Ulbrich, I. M., Canagaratna, M. R., Zhang, Q., Worsnop, D. R., and Jimenez, J. L.: Interpretation of organic components from Positive Matrix Factorization of aerosol mass spectrometric data, Atmos. Chem. Phys., 9, 2891-2918, doi:10.5194/acp-9-2891-2009, 2009.

Violaki, K. and Mihalopoulos, N.: Water-soluble organic nitrogen (WSON) in size-segregated atmospheric particles over the Eastern Mediterranean, Atmos. Environ., 44, 4339-4345, 2010.

Wang, F., Lin, T., Feng, J., Fu, H., and Guo, Z.: Source apportionment of polycyclic aromatic hydrocarbons in $\mathrm{PM}_{2.5}$ using positive matrix factorization modeling in Shanghai, China, Environmental Sciences Process Impacts, 17, 197-205, doi:10.1039/c4em00570h, 2015.

Wang, F., Guo, Z., Lin, T., and Rose, N. L.: Seasonal variation of carbonaceous pollutants in $\mathrm{PM}_{2.5}$ at an urban "su- persite" in Shanghai, China, Chemosphere, 146, 238-244, doi:10.1016/j.chemosphere.2015.12.036, 2016.

Wang, G., Kawamura, K., Lee, S., Ho, K., and Cao, J.: Molecular, seasonal, and spatial distributions of organic aerosols from fourteen Chinese cities, Environ. Sci. Technol., 40, 4619-4625, doi:10.1021/es060291x, 2006.

Wang, J., Geng, N. B., Xu, Y. F., Zhang, W. D., Tang, X. Y., and Zhang, R. Q.: PAHs in $\mathrm{PM}_{2.5}$ in Zhengzhou: concentration, carcinogenic risk analysis, and source apportionment, Environ. Monit. Assess., 186, 7461-7473, doi:10.1007/s10661-014-3940$1,2014$.

Wang, J., Ge, X., Chen, Y., Shen, Y., Zhang, Q., Sun, Y., Xu, J., Ge, S., Yu, H., and Chen, M.: Highly time-resolved urban aerosol characteristics during springtime in Yangtze River Delta, China: insights from soot particle aerosol mass spectrometry, Atmos. Chem. Phys., 16, 9109-9127, doi:10.5194/acp-16-91092016, 2016a.

Wang, J., Onasch, T. B., Ge, X., Collier, S., Zhang, Q., Sun, Y., Yu, H., Chen, M., Prévôt, A. S. H., and Worsnop, D. R.: Observation of fullerene foot in eastern China, Environ. Sci. Technol. Lett., 3, 121-126, doi:10.1021/acs.estlett.6b00044, 2016b.

Wang, T., Jiang, F., Deng, J., Shen, Y., Fu, Q., Wang, Q., Fu, Y., Xu, J., and Zhang, D.: Urban air quality and regional haze weather forecast for Yangtze River Delta region, Atmos. Environ., 58, 7083, doi:10.1016/j.atmosenv.2012.01.014, 2012.

Wang, Y., Zhuang, G., Zhang, X., Huang, K., Xu, C., Tang, A., Chen, J., and An, Z.: The ion chemistry, seasonal cycle, and sources of $\mathrm{PM}_{2.5}$ and TSP aerosol in Shanghai, Atmos. Environ., 40, 2935-2952, doi:10.1016/j.atmosenv.2005.12.051, 2006.

Xu, J., Zhang, Q., Li, X., Ge, X., Xiao, C., Ren, J., and Qin, D.: Dissolved organic matter and inorganic Ions in a central Himalayan glacier - Insights into chemical composition and atmospheric sources, Environ. Sci. Technol., 47, 6181-6188, doi:10.1021/es4009882, 2013.

Xu, J., Zhang, Q., Chen, M., Ge, X., Ren, J., and Qin, D.: Chemical composition, sources, and processes of urban aerosols during summertime in northwest China: insights from high-resolution aerosol mass spectrometry, Atmos. Chem. Phys., 14, 1259312611, doi:10.5194/acp-14-12593-2014, 2014.

Xu, J. Z., Zhang, Q., Wang, Z. B., Yu, G. M., Ge, X. L., and Qin, X.: Chemical composition and size distribution of summertime $\mathrm{PM}_{2.5}$ at a high altitude remote location in the northeast of the Qinghai-Xizang (Tibet) Plateau: insights into aerosol sources and processing in free troposphere, Atmos. Chem. Phys., 15, 50695081, doi:10.5194/acp-15-5069-2015, 2015.

$\mathrm{Xu}$, L., Guo, H., Weber, R. J., and Ng, N. L.: Chemical Characterization of Water-Soluble Organic Aerosol in Contrasting Rural and Urban Environments in the Southeastern United States, Environ. Sci. Technol., 51, 78-88, doi:10.1021/acs.est.6b05002, 2017.

Ye, X. N., Ma, Z., Hu, D. W., Yang, X., and Chen, J. M.: Size-resolved hygroscopicity of submicrometer urban aerosols in Shanghai during wintertime, Atmos. Res., 99, 353-364, doi:10.1016/j.atmosres.2010.11.008, 2011.

Zhang, Q., Jimenez, J. L., Canagaratna, M. R., Allan, J. D., Coe, H., Ulbrich, I., Alfarra, M. R., Takami, A., Middlebrook, A. M., Sun, Y. L., Dzepina, K., Dunlea, E., Docherty, K., DeCarlo, P. F., Salcedo, D., Onasch, T., Jayne, J. T., Miyoshi, T., Shimono, A., Hatakeyama, S., Takegawa, N., Kondo, Y., 
Schneider, J., Drewnick, F., Borrmann, S., Weimer, S., Demerjian, K., Williams, P., Bower, K., Bahreini, R., Cottrell, L., Griffin, R. J., Rautiainen, J., Sun, J. Y., Zhang, Y. M., and Worsnop, D. R.: Ubiquity and dominance of oxygenated species in organic aerosols in anthropogenically-influenced Northern Hemisphere midlatitudes, Geophys. Res. Lett., 34, L13801, doi:10.1029/2007g1029979, 2007a.

Zhang, Q., Jimenez, J. L., Worsnop, D. R., and Canagaratna, M.: A case study of urban particle acidity and its influence on secondary organic aerosol, Environ. Sci. Technol., 41, 3213-3219, doi:10.1021/Es061812j, 2007b.

Zhang, Q., Jimenez, J. L., Canagaratna, M. R., Ulbrich, I. M., Ng, N. L., Worsnop, D. R., and Sun, Y.: Understanding atmospheric organic aerosols via factor analysis of aerosol mass spectrometry: a review, Anal. Bioanal. Chem., 401, 3045-3067, doi:10.1007/s00216-011-5355-y, 2011.

Zhang, R., Jing, J., Tao, J., Hsu, S.-C., Wang, G., Cao, J., Lee, C. S. L., Zhu, L., Chen, Z., Zhao, Y., and Shen, Z.: Chemical characterization and source apportionment of $\mathrm{PM}_{2.5}$ in Beijing: seasonal perspective, Atmos. Chem. Phys., 13, 7053-7074, doi:10.5194/acp-13-7053-2013, 2013.
Zhang, Y. J., Tang, L., Yu, H., Wang, Z., Sun, Y., Qin, W., Chen, W., Chen, C., Ding, A., Wu, J., Ge, S., Chen, C., and Zhou, H.-C.: Chemical composition, sources and evolution processes of aerosol at an urban site in Yangtze River Delta, China during wintertime, Atmos. Environ., 123, 339-349, doi:10.1016/j.atmosenv.2015.08.017, 2016.

Zhao, M., Huang, Z., Qiao, T., Zhang, Y., Xiu, G., and Yu, J.: Chemical characterization, the transport pathways and potential sources of $\mathrm{PM}_{2.5}$ in Shanghai: Seasonal variations, Atmos. Res., 158-159, 66-78, doi:10.1016/j.atmosres.2015.02.003, 2015.

Zhou, J., Xing, Z., Deng, J., and Du, K.: Characterizing and sourcing ambient $\mathrm{PM}_{2.5}$ over key emission regions in China I: Watersoluble ions and carbonaceous fractions, Atmos. Environ., 135, 20-30, doi:10.1016/j.atmosenv.2016.03.054, 2016. 